\title{
DANIŞTAY KARARLARINDA İDARİ BAŞVURULAR
}

\author{
Administrative Applications in the Decisions of the Turkish Council of \\ State
}
Doç. Dr. Yasin SEZER*
Hüseyin BÍLGINN***

GİRIŞ, I. Etkisiz İdari Başvuru ve Etkili İdari Başvuru Ayrımı, II. Bir İdari İşlem veya Eylem Yapılmasına İlişkin Yapılan Başvurular, III. Mevcut Bir İdari İşlemin Kaldırılması veya Değiştirilmesine İlişkin Yapılan Başvurular, IV. Zorunlu İdari Başvurular, V. İsteğe Bağlı İdari Başvurular, VI. Anayasa Mahkemesinin İptal Kararı Üzerine Yapılan İdari Başvurular, VII. Düzenleyici İşlemin İptali Üzerine Yapılan İdari Başvurular, SONUÇ

\section{ÖZET}

Anayasanın 36.maddesi gereğince, herkes, meşru vasıta ve yollardan faydalanmak suretiyle yargı mercileri önünde hak arama hürriyetine sahiptir. Ancak, yargılama süreci uzun süreli ve ekonomik olarak masraflı bir süreçtir. Yarg1 yolu, hak aramada tek yöntem de değildir. Kişiler, dilek ve şikayetleri hakkında, idari makamlara başvurma hakkına sahiptir. Kişilerin dilek ve şikayetlerini iletmek için idari makamlara yaptıkları müracaatlar, idari başvurular olarak ifade edilmektedir. İdari başvuru yöntemi yarg1 yoluna oranla daha az masraflı ve daha kısa sürede neticelenebilecek bir yöntemdir.

Türk İdare Hukuku öğretisinde idari başvurular konusunda son dönemde bazı çalışmalar yapılmış olmasına rağmen konunun bütün

\footnotetext{
* Pamukkale Üniversitesi İIBF Kamu Yönetimi Bölümü İdare Hukuku Öğretim Üyesi.

** Denizli İdare Mahkemesi Üyesi.
} 
yönleriyle yeterince ele alınıp tartışıldığını söylemek mümkün değildir. $\mathrm{Bu}$ nedenle, idari başvurular konusunun farklı bakış açılarılyla yeniden incelenmesi ve tartışılması gerekir. Bu çalışmada, yargı önüne gelmiş̧ uyuşmazlıklardan yola çıkarak idari başvuru konusuna ilişkin Danıştay'ın bakış açısı ortaya konulmaya çalışılmıştır.

Anahtar Kelimler: İdari başvuru, zorunlu başvuru, ihtiyari başvuru, dilekçe hakk1, bilgi edinme hakkı

\section{ABSTRACT}

Article 36 of the Turkish Constitution clearly states that everyone has the right of litigation, either as plaintiff or defendant, and the right to a fair trial before the courts through lawful means and procedures. However, due to the fact that the process of litigation is long-lasting and costly, the right of litigation is not the only way of asserting one's rights. People also have the right to apply to the administrative authorities with their wishes or complaints. These applications to the administrative authorities regarding the wishes and complaints of persons are called administrative remedies. Administrative remedies are less costly and can be concluded faster.

It is not possible to say that issues regarding administrative remedies had already been fully covered in the doctrine of Turkish administrative law although some recent studies related to these subjects have been emerged. For that reason, the subject of administrative remedies shall be discussed and given some reviews by taking note of some different points of view. This study lays down the point view of the Turkish Council of State concerning administrative remedies by examining disputes that have passed through the court.

Keywords: Administrative application, compulsory application, optional application, right of petition, right to obtain information

\section{GİRIŞ}

İnsanoğlu sosyal bir varlık olarak, toplum içinde yaşamakta ve sürekli olarak diğer kişilerle veya devleti oluşturan organlarla ilişki içinde bulunmaktadır. Bu ilişkinin kapsamı, sınırları, uyması gereken kurallar, sosyal ilişkiye girdiği hukuk öznesine göre değişmektedir. Örneğin, özel hukuk kişisinin borsada işlem gören bir anonim şirketten hisse senedi satın alması özel hukuk ilişkisi niteliği taşımakta iken, yürütme organı olan idare ile ilgili yaptığı işlemlerin birçoğu da kamu hukuku ilişkisi niteliği taşımaktadır. Kamu hukukunu ilgilendiren ve kamu idarelerinin belli bir yönde işlem tesis etmesini amaçlayan bu ilişkilerin bir çoğu, ilgili hukuk 
öznesinin yapacağı dilek veya şikayet içeren kamusal başvuru ${ }^{1}$ yoluyla gerçekleşmektedir. Bir başka ifadeyle, kamusal başvuruların konusunu, kişilerin şikayet, itiraz, istek ile devletin üç önemli erki olan yasama, yürütme ve yarg1 organlarından herhangi birisine yapılan başvurular oluşturmaktadır².

Türk Hukuk Sisteminde, başvuru hakkı Anayasa ile güvence altına alınmıştır. 1982 Anayasası'nın 36., 40., ve 74. maddeleri başvuru hakkı ile ilgilidir ${ }^{3}$. Aynı şekilde İnsan Hakları Avrupa Sözleşmesi'nin 13. maddesi de bu konuyu düzenlemektedir ${ }^{4}$. 3071 sayılı Dilekçe Hakkının Kullanılmasına Dair Kanun da siyasi başvuruyu düzenlemesi yanı sıra idârî başvuru yollarında ilişkin hükümlerde içermektedir ${ }^{5}$. Öte yandan, Yargıtay da bir

${ }^{1}$ Lütfi Duran, "İdari Müracaatlar ve Bunların Karşısında İdarenin Sükutu”, İ. ̈̈.H.F.M. C XII, S.1, s.32.

${ }^{2}$ Ramazan Yıldırım, İdari Başvurular, 2.bası, Mimoza Yayınları, Konya, 2006, s.3.

31982 Anayasası Madde 36, "Hak arama hürriyeti": Herkes, meşru vasıta ve yollardan faydalanmak suretiyle yargı mercileri önünde davacı veya davalı olarak iddia ve savunma ile adil yargılanma hakkına sahiptir. Hiçbir mahkeme, görev ve yetkisi içindeki davaya bakmaktan kaçınamaz."

1982 Anayasası Madde 40, "Temel hak ve hürriyetlerin korunması" : Anayasa ile tanınmış hak ve hürriyetleri ihlal edilen herkes, yetkili makama geciktirilmeden başvurma imkanının sağlanmasını isteme hakkına sahiptir. Devlet, işlemlerinde, ilgili kişilerin hangi kanun yolları ve mercilere başvuracağını ve sürelerini belirtmek zorundadır. Kişinin, resmi görevliler tarafından vaki haksız işlemler sonucu uğradığı zarar da, kanuna göre, Devletçe tazmin edilir. Devletin sorumlu olan ilgili görevliye rücu hakkı saklıdır.

1982 Anayasası Madde 74, “Dilekçe hakkı” : Vatandaşlar ve karşılıklılık esası gözetilmek kaydıyla Türkiye'de ikamet eden yabancılar kendileriyle veya kamu ile ilgili dilek ve şikayetleri hakkında, yetkili makamlara ve Türkiye Büyük Millet Meclisine yazı ile başvurma hakkına sahiptir. Kendileriyle ilgili başvurmaların sonucu, gecikmeksizin dilekçe sahiplerine yazılı olarak bildirilir. Bu hakkın kullanılma biçimi kanunla düzenlenir.

${ }^{4}$ Avrupa İnsan Hakları Sözleşmesi Madde 13, "Etkili Başvuru Hakkı": Bu sözleşmede tanınmış olan hak ve özgürlükleri ihlal edilen herkes, ihlal fiili resmi görev yapan kimseler tarafindan bu sıfatlarına dayanılarak yapılmış da olsa, ulusal bir makama etkili bir başvuru yapabilme hakkına sahiptir.

5 “...davacıların ... İcra Hakimi hakkında yaptığı şikayetin, ilgili hakimin yargılama işlevi içinde verdiği karara, dolayısıyla yargılama faaliyetine ilişkin olduğu ve şikayet dilekçesinde öne sürülen hususların, hakimin verdiği karara karşı kanun yollarına başvuru nedeni olarak ileri sürülebileceği, olayda, şikayet edilen hakimin görevi sırasında işlediği ve sıfat ve görevleri gereğine uymayan tutum ve davranışının söz konusu olmadığının saptanarak, şikayetin yargı mercilerinin konusuna giren hususa ilişkin olduğu gerekçesiyle, buna ilişkin dilekçenin 3071 sayılı Kanunun 6/b maddesi uyarınca işleme konulmaması yolunda kurulan dava konusu işlemde hukuka aykırılık, aksi yöndeki İdare Mahkemesi kararında ise hukuksal isabet bulunmamaktadır.” Danıştay 5.D., 28.11.2006, E.2006/3461, K.2006/5738, Danıştay Dergisi, S.115, s.187.; “..Bu bakımdan, davacının bazı yargı mensupları hakkındaki şikayet dilekçesinin işleme konulmamasına ilişkin idari işleme karşı açılan davada, işin esasına girilerek söz konusu şikayet dilekçesinin 2802 sayılı Kanunun 97. maddesi ve 3071 sayılı Kanunun 6. maddesi kapsamında olup olmadığı yönünden hukuki değerlendirme yapılarak işin esası hakkında bir karar verilmesi gerekirken, sözü edilen işlemin idari davaya konu olamayacağı gerekçesiyle davanın incelenmeksizin reddi 
kararında ihbar ve şikayet yoluyla yapılan kamusal başvuruyu Anayasa'da öngörülen hak arama özgürlüğünün doğal sonucu olarak ele almıştır ${ }^{6}$.

Kamusal başvurular, yapılan başvurunun içeriği göz önüne alındığında, yargısal başvurular ve idari başvurular olmak üzere iki gruba ayrılır ${ }^{7}$. Bu sınıflandırmada, başvuru hakkının kullanılıp kullanılmadığı, başvuru sonucu izlenen usuller ve elde edilen sonuçlar nazara alınmaktadır ${ }^{8}$. Ancak, kamusal başvurular idari ve yargısal olarak sınıflandırıldığında, siyasal başvurular, ayrı bir kategoride ele alınmamakta ve idari başvuru kapsamında değerlendirilmektedir? ${ }^{9}$. Kişilerin yasama organına yaptıkları her türlü başvuruyu ifade eden siyasi başvurular, gerek izlenen usul gerekse uygulanan yaptırım bakımından idari başvurulardan farklılıklar taşımaktadır. Maddi açıdan yapılan bu tasnifin siyasal başvuruları açıklayamaması nedeniyle kamusal başvurular, başvurunun yapıldığı organa (organik tasnife) göre, idari başvurular, siyasi başvurular ve yargısal başvurular olmak üzere üç grupta tasnif edilmiştir ${ }^{10}$.

En genel ifade ile idari makamlara yapılan başvurular olarak ifade edilebilen idari başvuru kavramı, Yıldırım tarafından "kişilerin menfaatleri bulunan ve idari işlev kapsamına giren konularda, kamusal makamlara yaptıkları başvuruların tümü ${ }^{11}$ ile; kamu yararını korumak amacıyla, yetki

yolunda verilen İdare Mahkemesi kararında hukuka uyarlık bulunmamaktadır. Öte yandan; İdare Mahkemesi kararında maddi olay ortaya konulurken dava konusu işlemin, davacının şikayeti üzerine yapılan inceleme sonucuna göre ilgili savcılar hakkında sorușturma açılmamasına ilişkin olduğu belirtilmiş ise de; yapılan şikayet üzerine hakim ve savcılar hakkında disiplin veya ceza soruşturması açılmamasına, diğer bir anlatımla ilgililer hakkında işlem yapılmasına gerek olmadığına ilişkin Adalet Bakanlığı'nca kurulan işlemlerin, ancak şikayet dilekçesinin işleme konulmasından sonra verilebileceğini; dolayısıyla, şikayet dilekçesinin işleme konulmasından sonraki aşamada kurulması mümkün olan soruşturma açılmamasına ilişkin işlemlerin, dilekçenin işleme konulmamasına ilişkin ișlemlerle aynı nitelikte olmadığını vurgulamak gerekmiștir.” Danıştay 5.D., 28.11.2006, E.2006/2586, K.2006/5740, Danıştay Dergisi, S.115, s.190.

6 Yargitay 4.H.D., 15.03.1988, E:1987/10210, K:1988/2444, Yargitay Kararları Dergisi, C.XIV, S.11, 1988, s.1502.

${ }^{7}$ Yildirım, s. 9-11.

${ }^{8}$ Duran, s.132.

${ }^{9}$ Y Yldırım, s.15.

${ }^{10}$ Duran, s.132; Sıdık Sami Onar, İdare Hukukunun Umumi Esaslarl, 3.bası, İstanbul 1967, s.1813-4; Yildirım, s. 15.

11 "Kendi isteği ile belli bir tarih göstererek emekli olmak üzere başvuran; ancak belirtilen tarihten önce, emeklilik işleminin onayından sonra bu isteğinden vazgeçtiğini bildiren davacının, vazgeçme talebi kabul edilerek emeklilik onayının geri alınması gerekirken reddi yönündeki işlemde hukuka uyarlık görülmediği hakkındaki kararda Danıştay tarafindan emeklilik yapılan idârî başvurunun bu başvuru kabul edilmeden yapılacak yeni bir başvuru ile geri alınabileceğine karar vermiştir". Danıştay 11.D., 06.10.2004 E.2001/3220, K.2004/3925, Danıştay Dergisi, S.109, s.318; "isteğe bağlı emeklilik işleminin kurumun en yüksek amirinin onayıyla tekemmül ettiği ve onayla birlikte kamu görevlisi statüsü kazanan iştirakçinin daha sonra emeklilik isteminden vazgeçmesinin 
verilen kamu görevlilerinin veya kamu tüzel kişilerinin, diğer idari makamların yaptığı idari işlemlerin iptali, değiştirilmesi veya geri alınması gibi nedenlerle, yine yasaların gösterdiği idari işleve sahip makamlara yaptıkları İdare Hukukuna ilişkin başvurular" şeklinde tanımlanmıştır ${ }^{12}$.

Türk İdare Hukuku öğretisinde idari başvurular konusunda son dönemde bazı çalışmalar yapılmıştır. Ancak, konunun bütün yönleriyle yeterince ele alınıp tartışıldığını söylemek mümkün değildir. Bu konu, literatürde daha çok, idari yargılama hukuku ile ilgili eserlerde, iptal davasının kabul edilebilirlik şartları kapsamında incelenmiştir. Oysa ki, yukarıda kısaca değinildiği üzere, bu konu bireyin hak arama özgürlügünün yargısal yolların dışında da kullanılması açısından önemli olduğu gibi idarenin denetimi ve kamu yararının korunması açısından da önemlidir. $\mathrm{Bu}$ nedenle, idari başvurular konusu, farklı bakış açılarıyla yeniden incelenmesi ve tartışılması gereken bir konudur. Bu çalışmada Danıştay kararlarında idari başvurular ele alınacaktır. Diğer bir ifade ile bu çalışmada yargı önüne gelmiş uyuşmazlıklardan yola çıkarak idari başvuru konusuna ilişkin Danıştay'ın bakış açısı ortaya konulmaya çalışılacaktır.

\section{Etkisiz İdari Başvuru ve Etkili İdari Başvuru Ayrımı}

İdari başvurular, literatürde çeşitli açılardan sınıflandırılmaktadır ${ }^{13} . \mathrm{Bu}$ sınıflandırmalardan biri de idari başvuruların hukuki sonuçlarına göre yapılan sınıflandırmadır. Hukuki sonuçlarına göre, idari başvurular etkisiz idari başvurular ve etkili idari başvurular olarak ikiye ayrılabilir.

Etkisiz idari başvurular, herhangi bir hukuki sonuç doğurmayan, idareyi işlem veya eylem yapmaya zorlama gücü olmayan başvurulardır. Etkisiz idari başvuruların, iki türünden bahsetmek mümkündür. Birincisi, idarenin daha önce yaptığı bir işlem veya eyleme kaşı itiraz niteliğinde olmakla birlikte, yasanın öngördüğ̈̈ idari makamlara yapılmadığ 1 için beklenen hukuki sonucu doğurmayan başvurular. Örneğin, hiyerarşik üstü bulunmasına rağmen, işlemi yapan makamın kendisine itiraz etmek gibi. İkincisi ise, hukuken korunan hiçbir hakkı ya da menfaati olmadığı halde doğrudan doğruya idarenin bir işlem ya da eylem yapması için yapılan başvurulardır. Bu tür başvurular herhangi bir hukuki sonuç doğurmaz. Diğer bir deyişle, idarenin bu tür başvuruların içerdiği talepleri yerine getirme

emeklilik işlemini geri alınmasını gerektirmeyeceği hakkında”, Danıştay 5.D. 09.09.1999, E.1999/2302, K.1999/2444, Danıştay Dergisi, S.103, s.404.

${ }^{12}$ Yıldırım, s.30; Hamza Eroğlu, İdare Hukuku, 3.bas1, Ankara, 1978, s.358.; Duran idari başvuruları, "Fertlerin, menfaatleri bulunan hususlarda, merkeziyet veya ademi merkeziyet idarelerinde vaki olacak, amme hukukuna müteallik, bil cümle talep, iddia ve dilekleri idari müracaatı tazammum eder" şeklinde tanımlamıştır. Duran, s.135.

${ }^{13}$ Yildirim, s.64. 
yükümlülüğ̈̈ yoktur. Bu tür başvurular, dava açma süresi üzerinde durdurma etkisi göstermezler ${ }^{14}$.

Danıştay yetkili olmayan makama yapılan başvurunun işlemeye başlayan dava açma süresini durdurmayacağını ifade etmiştir ${ }^{15}$. Danıştay’a göre, "tapu kaydındaki okul alanı şerhinin kaldırılabilmesi için mevcut planı değiştirmeye yetkili olan belediyeye başvurulması gerektiğinden, yetkili olmayan valiliğe yapılan başvurunun cevap verilmemek suretiyle reddi yolundaki işlemde mevzuata aykırılık" yoktur ${ }^{16}$. Aynı şekilde, başvuru için mevzuatta öngörülen süre geçirildikten sonra yapılan başvuru da etkisiz idârî başvuru olmaktadır. Danıştay, mevzuatta öngörülen süre dolduktan sonra yapılan başvurunun ilgilisi lehine sonuç doğurmayacağına karar vermiştir ${ }^{17}$.

Danıştay, ilgili mevzuatta idari başvuru yolu öngörülmeyen hallerde yapılan idari başvuruları etkisiz idari başvuru olarak kabul ederek, söz konusu başvurunun dava açma süresini durdurmayacağına hükmetmiştir. "ETİ Krom A.Ş.Genel Müdür Yardımcısı ve Yönetim Kurulu Üyesi olarak görev yapmakta iken işlediği ileri sürülen fiili nedeniyle, 657 sayılı Devlet Memurları Kanununun (DMK) 125/D-f ve Teşekkül Personel Yönetmeliğinin 88/ö maddeleri uyarınca 2 yıl süre ile kademe ilerlemesinin durdurulması cezası ile cezalandırılmasına ilişkin Başbakanlık Disiplin Kurulunun 26.6.2000 günlü ve 3 sayılı kararının iptali istemiyle" açılan iptal davasının temyiz incelemesinde Danıştay, DMK'nun 135.maddesinde sadece uyarma ve kınama cezaları için itiraz hakkının düzenlendiği, kademe durdurması cezası için itiraz yetkisi düzenlenmediği için bu yöndeki başvuruyu etkili idari başvuru olarak kabul etmemiş ve "disiplin cezasına karş1 yapılan itirazın işlemeye başlamış olan dava açma süresini durdurmayacağı” gerekçesiyle davanın süre yönünde reddi yönünde karar vermiştir $^{18}$. Danıştay'ın içtihadı bir çok yönden eleştirilebilir niteliklidir. Öncelikli olarak, DMK'nun 135.maddesinde uyarma ve kınama cezaları için itiraz edilebileceği, aylıktan kesme, kademe ilerlemesinin durdurulması ve devlet memurluğundan çıkarma cezalarına karşı yarg1 yoluna gidilebileceği düzenlenmiştir. Danıştay, bu düzenlemeyi zımnî yasaklama olarak yorumlamış ve uyarma ve kınama cezalarının dışındaki cezalar için itiraz yolunu kapatmıştır. Oysa ki, kanunda açıkça yasaklayıcı bir hüküm yoktur. Hak arama hürriyeti açısından yargı yoluna nazaran daha kolay, daha kısa

\footnotetext{
${ }^{14}$ Şeref Gözübüyük-Güven Dinçer, İdari Yargılama Usulü, Turhan Kitabevi, Ankara, 1996, s.235.

${ }^{15}$ Danıştay 6.D., 26.02.1990, E.1988/833, K.1990/166, Danıştay Dergisi, S.80, s.243.

${ }^{16}$ Danıştay 6.D., 05.06.2003, E.2002/3200, K.2003/3476, Danıştay Kararları Dergisi, S.3, s.198.

${ }^{17}$ Danıştay 11.D., 10.04.2006, E.2006/232, K.2006/1710, Danıştay Dergisi, S.114, s.309.; Danıştay 8.D., 07.10.2003, E.2003/590, K.2003/3845, Danıştay Kararları Dergisi, S.3, s.257; Danıştay 11.D., 17.12.2007, E.2005/2183, K.2007/9780 (karar yayımlanmamıştır).

${ }^{18}$ Danıştay 12.D., 17.02.2006, E.2003/873, K.2006/473, (www.danistay.gov.tr: 13.06.2008).
} 
süreli ve daha az masraflı bir yol olan idari başvuru yolunun, kanunda açık bir yasaklama olmadığı müddetçe, var olduğunun kabulü gerekir

Diğer taraftan, son dönemde, kişilerin yargı yoluna gitmeden önce idari başvuru yoluyla haklarını alabilmelerine ilişkin gerek Anayasa'da ve gerekse yasalarda bir çok düzenleme yapılmıştır. Anayasa'ya göre, "vatandaşlar ve karşı1ıklılık esası gözetilmek kaydıyla Türkiye'de ikamet eden yabancılar kendileriyle veya kamu ile ilgili dilek ve şikayetleri hakkında, yetkili makamlara ve Türkiye Büyük Millet Meclisi'ne yazı ile başvurma hakkına sahiptir"'(m.74). Yine, 1982 tarihli ve 2577 sayılı İdari Yargılama Usulü Kanununun 11.maddesinde, kişilerin idari yargıya gitmeden önce idari işlemin kaldırılması geri alınması veya değiştirilmesi amacına yönelik başvuru yapabileceği öngörülmüştür.

Danıştay'ın söz konusu kararında, DMK'nun özel kanun olması itibariyle 2577 sayılı Yasada öngörülen düzenlemenin bu olayda uygulanamayacağından bahsedilmektedir. Teorik olarak genel kanun karşısında özel kanun hükümlerinin uygulanması gerektiği kabul edilmekle birlikte, söz konusu genel kanun tarih itibariyle daha sonra yapılmış bir kanundur ve kanun koyucunun iradesi de idari başvurunu yolunu açmak yönündedir. Dolayısıyla, kanunda açıkça yasaklayıcı bir hüküm olmadığı halde "sırf kanunda olmadığı" gerekçesiyle, bazı disiplin cezalarında idari başvuru yolunun kapatılması hakkaniyete aykırı olduğu gibi, usul ekonomisi açısından da uygun bir yorum değildir.

Danıştay bir başka kararında ise, "davacının bir banka şubesinde bulunan hesaplarının üçüncü kişilere açılanması nedeniyle sorumlular hakkında işlem yapılması ve cumhuriyet savcılığına suç duyurusunda bulunulması istemiyle BDDK'ya yaptığ 1 başvurunun reddine ilişkin işlemin

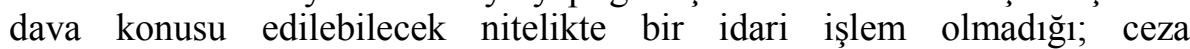
kovuşturması açılması için kurumun cumhuriyet savcılığına başvurması ya da başvurmamasının ceza yargılaması alanını ilgilendirdiğine karar vermiştir. Danıştay tarafından davalı idare olan BDDK'ya yapılan başvuru etkisiz bir idârî başvuru olarak kabul edilmiş ve idârî başvuruya verilen cevabın idârî yargı denetimine tabi olmadı $\breve{g}_{1}{ }^{19}$ ifade edilmiştir.

Burada 3071 sayılı Dilekçe Hakkının Kullanılmasına Dair Kanunun 5.maddesine değinmekte yarar vardır. Kanuna göre, başvuru dilekçesi, "konusuyla ilgili olmayan bir idari makama verilmesi durumunda, bu makam tarafından yetkili idari makama gönderilir ve ayrıca dilekçe sahibine de bilgi verilir". Bu durumda, başvuru etkili idari başvuru olarak hukuki sonuç doğurur. Yıldırım, yetkisiz makama yapılan başvurunun dava açma süresi içinde yetkili makama gönderilirse, geliş tarihinden itibaren hukuki

19 Danıştay İdari Dava Daireleri Kurulu, 23.06.2006, E.2006/871, K.2006/759, Danıştay Dergisi, S.114, s.81. 
sonuç doğuracağını ifade etmektedir ${ }^{20}$. Kanaatimizce, başvurunun etkili bir başvuru sayılabilmesi için dava açma süresi içinde gönderilme şartı aranmamalıdır. Aksi takdirde kurumlar arası yazışmalarda yaşanan gecikmeler nedeniyle dava açma süresinin dolma ihtimali çok yüksektir. Bu durumda 5.maddedeki düzenlemeden beklenen yarar hâsıl olmayacaktır.

Etkili idari başvurular, idareyi işlem veya eylem yapma yükümlülüğü altına sokan başvurulardır ${ }^{21}$. Etkisiz idârî başvuruların aksine, etkili idari başvuruların reddi halinde başvuru sahibi idari yargıda iptal veya tam yargı davası açarak mağduriyetinin giderilmesini isteyebilir ${ }^{22}$. Bir başvurunun etkili başvuru sayılması için, menfaat ilişkisinin varlığı yeterlidir. Bir hak ihlalinin olması zorunlu değildir. Danıştay'a göre, hastaneye sevk edilme isteğine ilişkin başvuru etkili bir idârî başvurudur ${ }^{23}$.

2003 y1lında "demokratik ve şeffaf yönetimin gereği olan eşitlik, tarafsızlık ve açıklık ilkelerine uygun olarak kişilerin bilgi edinme hakkını kullanmalarını" sağlamak amacıyla 4982 sayılı Bilgi Edinme Hakkı Kanunu yapılmıştır. Kanun uyarınca, kişiler kamu kurum ve kuruluşların ellerinde bulunan veya görevleri gereği bulunması gereken bilgi veya belgeleri alma hakkına sahiptirler. Danıştay, Bilgi Edinme Hakkı Kanunu uyarınca yapılan başvuruları etkili idari başvuru olarak kabul etmiş̧tir. Danıştay, Fatih Belediyesinde zabıta memuru olarak görev yapan davacının zabıta müdür yardımcılığı kadrosuna atanmak isteğinin reddine ilişkin işlemin iptali için açılan davada, davacının "zabıta müdür yardımcılığına atama yapıldığını öğrenmesi üzerine yapılan atamanın hangi ölçüt ve gerekçeyle yapıldığı, kendi atamasının niçin yapılmadığını" öğrenmek amacıyla Bilgi Edinme Kanunu çerçevesinde yaptığı başvuruyu etkili idari başvuru kabul ederek, bu başvuruya verilen cevabı da idârî davaya konu olacak kesin ve yürütülmesi gerekli bir idari işlem olarak kabul etmiştir ${ }^{24}$. Benzer bir kararda Danıştay, 4054 sayılı Rekabetin Korunması Hakkında Kanun uyarınca hakkında soruşturma açılan davacı şirketin soruşturma ile ilgili tüm bilgi ve belgelerin

\footnotetext{
${ }^{20}$ Y1ldirım, s.132.

${ }^{21}$ Yildirim, s.69.

22 Danıştay 10.D., 17.10.2006, E.2003/3265, K.2006/5765, Danıştay Dergisi, S.114, s.294; Hastaneye sevk edilme isteğinin etkili bir idârî başvuru olduğu hakkında, Danıştay 5.D., 28.12.2005, E.2003/7204, K.2005/6508, Danıştay Dergisi, S.112, s.178; Danıştay 11.D., 21.12.2005, E.2003/3693, K.2005/6016, Danıştay Dergisi, S.112, s.319.

${ }^{23}$ Danıştay .5.D., 28.12.2005, E.2003/7204, K.2005/6508, Danıştay Dergisi, S.112, s.178; Ayrıca Danıştay bir başka kararında da "Eğitim uzmanı olan davacının personel genel müdürlüğünde daire başkanlığı görevini yürüttüğü dönemine ilişkin, yapılan inceleme sonucu düzenlenen müfettiş raporunda yer alan bir daha yöneticilik görevi verilmemek üzere görevden alma ve kınama cezası verilmesi teklifinin kaldırılması istemiyle yaptı̆̆ başvurunun reddine ilişkin işlemin kesin ve yürütülebilir işlem" olduğuna karar vermiştir. Danıştay 12.D., 13.04.2005, E.2004/4077, K.2005/1353, Danıştay Dergisi, S.110, s.348.

${ }^{24}$ Danıştay 5.D., 17.09.2007, E.2007/1074, K.2007/4662, Danıştay Dergisi, S.117, s.163; Danıştay 2.D., 17.04.2007, E.2007/145, K.2007/1752, Danıştay Dergisi, S.116, s.123.
} 
kendisine verilmesi istemini etkili bir idârî başvuru kabul ederek, aksi yönde tesis edilen işlemin iptaline karar vermiştir. Danıştay kararında, "4054 sayılı Kanunun 44.maddesinin ikinci fikrası uyarınca sözlü savunma hakkının kullanılması taleplerine kadar kurum bünyesinde kendileri ile ilgili düzenlenmiş her türlü evrakın ve mümkünse elde edilmiş her türlü delilin bir nüshasının verilmesinin istenebileceği,....Kurum tarafindan her başvurunun soruşturmanın sürecinin olumsuz yönde etkileyip etkilemeyeceği değerlendirilerek gerekçelerini belirtmek suretiyle bir işlem tesis edileceği, ......belirtilen hususlar gözetilmeksizin belli gerekçelerden hareketle tüm soruşturmalarda uygulanmak üzere alınan ilke karar niteliğindeki Rekabet Kurulu işleminin" hukuka aykırı olduğu belirtilerek iptal edilmiştir ${ }^{25}$.

1136 sayıl1 Avukatlık Kanununun 157. maddesi uyarınca Cumhuriyet Savcısı tarafından yapılan idari başvuru bir etkili idari başvuru olmasına rağmen başvurunun reddi üzerine Cumhuriyet Savcısının idari yarg1 yerinde ret işlemine karşı iptal davası açma yetkisi bulunmamaktadır. Bu yönüyle, Cumhuriyet Savcısının yapmış olduğu bu başvuru etkili idari başvurulardan ayrilmaktadır.

İdari başvuruların hukuki sonuçları, yapıldıkları makama göre de değişebilmektedir. İdari işlemi yapan makama yapılan başvurular, dava açma süresini durdurucu bir etkiye sahiptir. Ancak, bunun için işlemi yapan makamın hiyerarşik bir üstü bulunmamas ${ }^{26}$ veya yasalarca başvurusu zorunlu olan ayrı bir başvuru makamı olmaması ${ }^{27}$ gerekir $^{28}$. Hiyerarşik makam veya zorunlu idari başvuru makamı var iken işlemi tesis eden makama yapılan başvurular işlemeye başlamış olan dava açma süresini durdurmaz ${ }^{29}$. Ayrıca idari işlemi tesis eden makama yapılacak olan bu

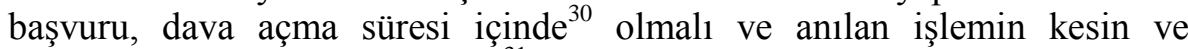
yürütülebilir bir nitelikte olmas ${ }^{31}$ ve işlemi tesis eden makama işlemini geri alması, kaldırması, değiștirmesi veya iptal etmesi istemiyle başvuru yapılmalıdır ${ }^{32}$. Hemen belirtelim ki, işlemi tesis eden makama yapılan bu tür

${ }^{25}$ Danıştay 13.D., 07.05.2007, E.2006/981, K.2007/2812, Danıştay Dergisi, S.117, s.370.

${ }^{26}$ Danıştay 12.D., 23.10.1973, E.1973/548, K.1973/2549, Kazım Yenice - Yüksel Esin, Açıklamalı - Içctihatlı - Notlu İdari Yargılama Usulü, Ankara, 1983, s.215.

${ }^{27}$ Danıştay 6.D., 06.11.1968, E.1967/1800, K:1968/2909, Yenice/Esin, s.215.

${ }^{28}$ Yildirim, s.138-139.

${ }^{29}$ Yenice/Esin, s.215.

${ }^{30}$ Danıştay 5.D., 02.05.2005, E.2004/6392, K.2005/2326, Danuştay Dergisi, S.110, s.185.

${ }^{31}$ Yıldırım, İdari Başvurular, s.140-141.

${ }^{32}$ Erol Çırakman, “İdari Davalarda Süre”, İdare Hukuku ve İdari Yargı ile İlgili Íncelemeler, C:1, Ankara, 1976, s. 210; "1.derece intibak1 üzerinden aylık almakta iken emeklilik isteminde bulunan, ancak 2. Derece 4. Kademe üzerinden emekli aylığı bağlanan davacının emeklilik iradesi 1. Derece intibakına göre gerçekleştiğinden, emeklilik onayının iptali istemiyle yapılan başvurunun reddi yolundaki işlemde hukuka uyarlık bulunmadı̆̆ 
idari başvurular, idarelerin de kendilerini hukukilik ve yerindelik denetimini kapsayan bir öz denetime tabi tutmasını sağlar ${ }^{33}$.

Hiyerarşik makama yapılan idari başvuruların hukuki sonuçlarına gelince, dava açma süresi içinde yapılan hiyerarşik başvuru, dava açma süresini durdurur ${ }^{34}$. Hiyerarşik başvuru sonucu duran dava açma süresi idarenin açık veya zımni cevabı üzerine yeniden işlemeye başlar ${ }^{35}$. Hiyerarşik başvurunun dava açma süresini durdurabilmesi için, dava açmadan önce zorunlu olan bir idari başvuru yolunun öngörülmesi, hiyerarşik makama başvurunun yapılmas ${ }^{36}$, kesin ve yürütülebilir bir idari işlemin geri alınması, iptali, kaldırılması veya değiştirilmesi istemiyle bu başvurunun yapılmas $1^{37}$, başvuruya konu idari işlemin kesin nitelikte ${ }^{38}$ olmamas1 ve başvurunun mevzuatın öngördüğü süre içinde yapılması gereklidir $^{39}$.

"Telekomünikasyon piyasasinda 4054 sayll Kanunun ihlal edilip edilmediği, soruşturma açılması gerekip gerekmediğini belirlemek amacıyla ön araştırma yapılması yolunda verilen kurul kararı doğrultusunda yetkililerce yerinde inceleme yapılmasına izin verilmediğinden bahisle Rekabet Kurulunun ... günlü, ... sayılı kararı ile 4054 sayıl Kanunun 16/b ve 17/d maddeleri uyarınca davacı firma adına verilen para cezalarına yapılan itiraz üzerine 4054 sayll Kanunun 17. maddesi "d" fikrasina yönelik itirazın reddine ilişkin olarak verilen ... günlü, ... sayll Rekabet Kurulu Kararının iptali istemiyle" açılan davada Danıştay onuncu Dairesi "Rekabet Kurulu kararlarının, kesin ve yürütülmesi zorunlu idari işlemler olduğu, bu kararlara karşı ilgililerin başvuru yollarının 2577 sayılı Kanunun 11. maddesine göre özel hüküm niteliğinde olan, dolaylslyla öncelikle uygulanmasi gereken 4054 sayll Kanunun 55. Maddesinin birinci fikrasinda düzenlendiği, anılan kanun hükmü uyarınca işlem tesis eden davalı idarenin bu işlemine karşı dava yolundan başka başvurulabilecek bir idari itiraz yolu öngörülmediği” gerekçesiyle dava konusu işlemin davacıya yönelik kısmının iptaline karar vermiştir. Davalı idarenin temyiz talebi üzerine Danıştay İdari

hakkında", Danıştay 11.D., 21.12.2005, E.2003/3693, K.2005/6016, Danıştay Dergisi, S.112, s.319.

${ }^{33}$ Duran, s.149.

${ }^{34}$ Yildırım, s. 143.

35 Selçuk Soybay, "İdarenin Yargısal Olmayan Biçimlerde Denetimi”, (Yayınlanmamış Doktora Tezi), İ.Ü.S.B.Enstitüsü, s.48.

${ }^{36}$ Danıştay 8.D., 11.09.1990, E.1990/1348, K.1990/873, Danıştay Dergisi, S.82-83, s.710.

${ }^{37}$ Cirakman, s.210.

38 İdari anlamda kesin nitelikte işlemlerde vardır. Bu işlemlere örnek olarak 3091 sayılı yasa uyarınca mülki idari amirlerince taşınmaza yapılan müdahale veya tecavüzlerin önlenmesi istemleri hakkında verdikleri kararlar idari anlamda kesin nitelikteki kararlardır. Hüseyin Bilgin, Belediyelerin Taşınmaz Mal Zilyetliğine Yapılan Tecavüzlerin İdari Yoldan Önlenmesi, Mahalli İdareler Derneği Yayınları, Ankara, 2005, s.97.

${ }^{39}$ Yildirım, s. 143-149. 
Dava Daireleri Kurulu da aynı gerekçelerle Daire kararını oy çokluğu ile onamıştır ${ }^{40}$.

Yukarıda açıklandığı üzere, Danıştay'ın bu kararı eleştiriye açıktır. Şöyle ki, 4054 sayılı Kanunda itiraz yolu öngörülmemiş olması, söz konusu kurul kararlarına kaşı 2577 sayılı Kanunun 11. maddesi anlamında itiraz edilemeyeceği anlamına gelmez. Bilakis, özel kanunda hüküm olmayan durumlarda genel kanun hükümleri uygulanır prensibince Rekabet Kurulu kararlarına 2577 sayılı Kanunun 11.maddesi gereğince itiraz edilebilmesi gerekir. Nitekim bazı üyeler, "4054 sayll Kanunda, özellikle 52. maddesinde Rekabet Kurulu kararlarına yönelik olarak idari usul açısından idareye itiraz yolunun düzenlenmemiş yada öngörülmemiş olması, anılan kararlara karşı 2577 sayılı Kanunun 11. maddesi anlamında itiraz edilemeyeceği anlamına gelmemektedir. Çünkü 4054 sayılı Kanunun gerek 52 inci maddesi, gerekse 55. maddesinde itiraz yolunu kaldıran bir düzenleme yer almamaktadır. Bu durumda, Rekabet Kanununun 52. maddesinde, Kurul kararlarına karşı idari usul çerçevesinde bir başvuru yolunun gösterilmemesi, 55. maddesinde ise sadece yargı yolu olarak Danıştay'a başvurulabileceğinin belirtilmesi karşısında; Rekabet Kurulu kararlarına karşı, 2577 sayıl İdari Yargılama Usulü Kanununun 11. maddesi kapsamında kararın kaldırılması, geri alınması yada değiş̧irilmesi için başvurulabileceği, yapılan bu başvuruların Kurulca incelenebileceğinin kabulü gerekir" gerekçesiyle, haklı olarak çoğunluğun görüşüne katılmamıștır.

\section{Bir İdari İşlem veya Eylem Yapılmasına İlişsin Yapılan Başvurular}

İdari Yargılama Usulü Kanunu'na göre, “ilgililer, haklarında idari davaya konu olabilecek bir işlem veya eylemin yapılması için idari makamlara başvurabilirler. Altmış gün içinde bir cevap verilmezse istek reddedilmiş sayılır. İlgililer altmış günün bittiği tarihten itibaren dava açma süresi içinde, konusuna göre Danıştay'a, idare ve vergi mahkemelerine dava açabilirler. Altmış günlük süre içinde idarece verilen cevap kesin değilse ilgili bu cevabı, isteminin reddi sayarak dava açabileceği gibi, kesin cevabı da bekleyebilir. $\mathrm{Bu}$ takdirde dava açma süresi işlemez. Ancak, bekleme süresi başvuru tarihinden itibaren altı ayı geçemez" (m.10).

\footnotetext{
${ }^{40}$ Danıştay İdari Dava Daireleri Kurulu, 16.06.2005, E.2003/428, K.2005/2175, Danıştay Dergisi, S.111, s.79; Aynı yönde, Danıştay 10.D., 14.11.2002, E.2000/260, K.2002/4360, Danıştay Kararları Dergisi, S.1, s.411; "Kademe ilerlemesinin durdurulması cezasına karşı idârî başvuru yolu öngörülmediği hakkında", Danıştay 12.D., 7.02.2006, E.2003/783, K.2006/473, Danıştay Dergisi, S.113, s.395; "Devlet memurluğundan çıkarma cezasına karşı idârî başvuru yolu olmadığı hakkında", Danıştay 12.D., 26.04.2005, E.2004/2625, K.2005/1603, Danıştay Dergisi, S.110, s.343.
} 
İdarenin her hangi bir işlemi yok iken yapılan idari başvurular, idareyi belli bir yönde işlem tesis etmeye zorlamaktadır. İdarenin bu başvuruları susma suretiyle cevaplaması başvurunun zımnî reddi olarak düzenlenmiştir. İdarenin yapılan başvuruyu açıç̧a veya zımnen reddi üzerine dava açma süresi işlemeye başlar. 2577 sayılı Yasanın 10. maddesine göre yapılan başvuruya cevap verilmemesi yoluyla oluşan ret işleminden sonra idarece bir yanıt verilirse dava açma süresinin işleyeceği, maddede öngörülen 6 aylık bekleme süresinin sadece, idarece kesin olmayan bir yanıtın verilmesi ${ }^{41}$ halinde uygulanacağı uygulama da genel kabul gören düşüncedir ${ }^{42}$.

Danıştay'ın 2577 sayılı Yasanın 10. maddesiyle ilgili olarak çeşitli kararları bulunmaktadır. Bunlardan birinde, 6 . Daire tarafindan, imar planları mülkiyet hakkıyla ilgili olduğu ve bu mülkiyet hakkının kullanılabilmesi için imar durumu alınmış olması halinde, daha önce imar durum belgesi almış fakat bu belgeyi aldığ 1 tarihten itibaren dava açma süresi içinde imar planına karşı dava açmamış bir kişinin, daha sonra aynı konuda idareye imar durum belgesi almak istemiyle başvurması ve başvuruya verilen cevap (imar durum belgesi alması) üzerine imar planına karşı dava açılmasına bir engel bulunmadığına karar vermiştir ${ }^{43}$. Burada 6 . Daire tarafından imar durum belgesi almak amacıyla her zaman başvuru yapılabileceği kabul edilmiş olmaktadır. Yine aynı Daire tarafindan Belediye encümeni kararıyla tesis edilen yıkım işlemine karşı, 2577 sayılı Yasanın 11.maddesinde öngörülen usule göre dava aç1labileceği kabul edilmektedir ${ }^{44}$.

41 “2577 sayılı İdari Yargılama Usulü Yasasının 10/2 maddesinde, 10.6.1994 tarihinde 4001 sayılı Yasayla yapılan değişiklikle kesin olmayan cevaba karşı dava açılabileceği öngörülmüş olup yargılama usulünde davacı lehine yapılan değişikliğin davacı hakkında uygulanması hukukun genel ilkeleri gereği olduğundan davacının 2577 sayılı Yasanın 10. maddesi kapsamında yaptığı başvuruya verilen cevabın yine bu madde kapsamında değerlendirilerek dava konusu olup olmayacağının belirlenmesi gerekir. Bu durumda idare mahkemesince davacının başvurusuna idarece verilen cevabın 2577 sayılı Yasanın 10. maddesinde değişiklik yapan 4001 sayılı Yasanın 5. maddesi gereğince dava konusu yapılıp yapılmayacağı tartışılarak bir karar verilmesi gerekirken bu husus tartışılmadan işlemin kesin ve yürütülebilir nitelikte bir işlem olmadığı gerekçesiyle davanın reddine karar verilmesinde hukuka uyarlık bulunmamaktadır." Danıştay 10.D., 12.04.2000, E.1997/280, K.2000/1490, Danıştay Dergisi, S.104, s.546; Danıştay 8.D., 25.10.2000, E.1998/7093, K.2000/6612, Dantştay Dergisi, S.105, s.464.

${ }^{42}$ Sabri Coşkun- Müjgan Karyağdı, İdari Yargılama Usulü, Seçkin Kitabevi, Ankara, 2001, s. 215.

43 Danıştay 6.D., 09.03.2007, E:2005/214, K:2007/1461, Danıştay Dergisi, S.116, s.191; Danıştay 6. Daire bir başka kararında ise, yargı kararının kesinleşmesinden itibaren 30 gün içinde mahkeme kararının gereğini yerine getirmeyen idareye karşı; davacının, sonraki 60 gün içinde yargı kararına göre işlem yapılmaması nedeniyle, uğranılan zararın tazmini istemiyle dava açması gerektiğine karar vermiş ve bu tarih geçtikten sonra yapılan idârî başvurunun reddi üzerine açılan davanın ise, süresinde kabul edilemeyeceğine karar vermiştir. Danıștay 6.D., 30.01.2007, E.2004/831, K.2007/453, Danıștay Dergisi, S.116, s.203.

44 Danıştay 6.D., 12.05.2004, E.2004/492, K.2004/2973, Danıştay Kararları Dergisi, S.6, s.171. 
Danıştay 11. Dairesi ise, 10. maddenin uygulanmasıyla ilgili olarak bir kararında, düzenleyici işlemin iptal edilmesi üzerine, bu iptal kararının hukuki sonuçlarından yararlanmak amacıyla, 2577 sayılı Yasanın 10. maddesi uyarınca yapılan başvurunun reddine ilişkin işleme karşı yasal süresi içinde dava açılmadığı takdirde, aynı istemle ikinci kez yapılan başvurunun, daha önce geçen dava açma süresini ihya etmeyeceğine hükmetmiştir $^{45}$. Bir önceki Danıştay kararından farklı olarak 11. Daire, 2577 sayılı Yasanın 10. maddesinin bir kez başvurulacağı ve bu başvuru üzerine verilen ret cevabına karşı dava açılmadığı takdirde artık yeniden 10. madde kapsamında bir başvuru yapılamayacağını vurgulamaktadır.

2577 sayılı Yasanın 10. maddesi uyarınca işlem tesis edilmeden önce yapılan başvurularla ilgili olarak Danıştay 12. Dairesinin farklı kararları bulunmaktadır. Davacının öğretmenliğe atanma istemiyle çeşitli tarihlerde yapmış olduğu başvuruların her biri 2577 sayılı Yasanın 10 maddesi kapsamında kabul edilerek davalı idarece verilen her bir cevapta ayrı ayrı dava konusu edilebilecek işlem niteliğinde olduğu ve davacının en son başvurusuna verilen cevabın reddi üzerine açılan davanın süre aşımı yönünden reddedilemeyeceğine karar vermiştir ${ }^{46}$. 12. Daire, bu kararıyla aslında 10. madde kapsamında ilgilisinin her zaman idareye başvurarak idârî işlem tesisine zorlayabileceğini kabul etmiştir ${ }^{47}$. Ancak, aynı dairece verilen bir başka kararda ise yukarıda söz edilen her zaman başvuru yapabilme imkanı kabul edilmemiştir. 12. Daire, "askerlik hizmet süresinin rütbe terfiinde kabul edilmemesine ilişkin yasa hükmünün iptal edilmesi üzerine", askerlik hizmet süresinin rütbe ve terfi süresinden sayılması istemiyle başvuru yapan ve başvurusu zımnen reddedilen ve bu ret işlemine karşı dava açmayan davacının daha sonra aynı taleple yeniden yapmış olduğu başvurunun geçirilmiş olan dava açma süresini canlandırmayacağına ve davanın süre aşımı nedeniyle reddi gerektiğine karar vermiştir ${ }^{48}$. Dairenin bu kararı eleştiriye açık bir karardır. Kanaatimizce, 10. madde uyarınca idareyi bir işlem tesis etmeye her zaman zorlamak idâri istikrar açısından doğru olmasa da, rütbe terfi gibi bir takım geleceğe yönelik olan ve belirli zaman dilimlerinde tekrarlanan olaylarda 10. maddeye dayalı olarak her zaman

${ }^{45}$ Danıştay 11.D., 05.12.2006, E.2006/2456, K.2006/5631, Danıştay Dergisi, S.116, s. 353.

46 Danıştay 12.D.,13.02.2007, E:2004/2818, K.2007/543, Danıştay Dergisi, S.116, s.379.; Danıştay 10 Dairesi ise bir kararında, iptali istenilen düzenlemeden davacının önceden yaptığı başvurular nedeniyle bilgisinin bulunduğunun kabulü zorunlu olduğundan sonradan yapılan başvuru üzerine açılan davanın süre aşımı nedeniyle reddi gerektiğine karar vermiştir.D.10.D.KT:15.10.2003 gün ve E:2003/1377, K:2003/3999 sayılı kararı, Danıştay Kararları Dergisi, S.3, s.286.

${ }^{47}$ Bir başka kararda, anılan dairece, ilk defa veya yeniden kamu hizmetlerine atamalarla ilgili her zaman idareye başvurarak atama isteklerinde bulunacaklarından, bu tür başvuruların 2577 sayılı yasanın 11. maddesi kapsamında değerlendirilmesinde hukuka uyarlık bulunmadığına hükmedilmiştir. Danıştay 12.D., 07.10.1999, E.1998/2516, K.1999/1757, Danıştay Dergisi, S.103, s.981.

${ }^{48}$ Danıştay 12.D., 08.04.2008, E.2006/2730, K.2008/2106, (yayımlanmamış karar). 
başvuru yapılabilmelidir. Aksinin kabulü ise, eşitler arası eşitsizliğe neden olmaktadır. Nitekim olayımızdaki davacının açtığı dava süre aşımından reddedildiği halde, onunla aynı durumda olup daha önce herhangi bir başvuru yapmamış olan kişi hakkı olan bir davayı kazanıp, rütbe ve terfisini daha erken yapabilirken, davası süre aşımından reddedilen davacı bunu alamamaktadır.

İdareye belli konuda işlem tesisi için yükümlülük getiren yasa kuralına karşın, idarenin hareketsiz kaldığı durumlarda ya da belli bir göreve veya kadroya atama gibi zaman içinde koşulların değişmesi nedeniyle idarenin yeni bir değerlendirme yapmasını gerektiren konularda, 2577 sayılı Kanunun 10. maddesi uyarınca idareye başvurulup, dava açılabileceği de Danıştay tarafindan kabul edilen bir husustur ${ }^{49}$.

Danıştay 2. Dairesi, 10. madde uyarınca yapılacak olan başvurularla ilgili bir kararında, 01.01.2002 tarihinden itibaren kamu personeline ilişkin olarak gerçekleştirilen idari tasarruflardan kaynaklanan harcırah ödemelerinin gerçekleştirilmesinin idareler açısından bir zorunluluk olduğu (6245 say1lı Harcırah Kanunu kapsamında bulunan kurum ve kuruluşlarda; 22.7.2003 tarihinden itibaren ilk defa veya yeniden göreve alınanlar ile 27.4.2005 tarihinden itibaren zorunlu yer değiştirme, sınav, sağlık sebepleri ve eş durumu dışında kendi yazılı talepleri üzerine naklen atananlar haricinde); anılan tarihten sonra oluşan ve kamu personeli açısından belirsizlikler içeren bir hukuksal ortamda harcırahını alamayanların, bu belirsizlik ortamının yargısal süreç sonrasında hukuksal aydınlığa kavuşması ile birlikte yapacakları başvuruların, 2577 sayılı Kanunun 10. maddesi kapsamında görülmesi ve başvurulara ilişkin olarak tesis edilen işlemlere karş1 açılacak idari davalarda dava açma süresinin, anılan maddede yer alan sistematiğe göre değerlendirilmesi gerektiğine hükmetmiştir ${ }^{50}$.

Danıştay tarafindan Anayasa Mahkemesi tarafindan bir kanun hükmünün iptal edilmesi üzerine oluşacak yeni hukuki durumlarda da, idareye 2577 sayılı Yasanın 10 maddesi kapsamında bir başvuru yapılabileceği kabul edilmektedir ${ }^{51}$.

Öte yandan Danıştay tarafından bir düzenleyici işlemin iptal edilmesi halinde, bu düzenleyici işlemin iptali üzerine oluşan yeni hukuki durumdan faydalanmak amacıyla yapılacak olan başvurular da 2577 sayılı Yasanın 10 maddesi kapsamında değerlendirilmektedir ${ }^{52}$. Ancak ilgilisi tarafından

49 Danıştay 5.D., 15.09.2003, E.2003/1007, K.2003/3368, Danıştay Kararları Dergisi, S.3, s.171.

${ }^{50}$ Danıştay 2.D., 23.12.2005, E.2004/7942, K.2005/4297, (www.danistay.gov.tr: 22.06.2008).

51 Danıştay İdari Dava Daireleri Kurulu, 08.06.2006, E.2006/231, K.2006/542, Danıştay Dergisi, S.114, s.79.

52 Danıştay 11.D., 27.01.2006, E.2003/3204, K.2006/213, Danıştay Dergisi, S.113, s.344; Danıştay 11.D., 08.05.2006, E.2006/550, K.2006/2142, Danıştay Dergisi, S.113, s.356. 
yapılacak olan bu başvuruda istenilmeyen bir husus daha sonra başvurunun reddi halinde de istenilemez ${ }^{53}$. Bu konu ileride tekrar ele alınacaktır.

Burada Danıştay'ın bizce önemli bir kararına değinmekte yarar vardır. Danıştay, profesörlük kadrosu için yapılan başvuru üzerine kesin bir işlem tesis edilmeden profesörlük atamasıyla ilgili olarak idarece yürütülmesi gereken bir dizi işlem için öngörülen sürelerin davanın açılmasına ilişkin sürelerin hesaplanmasinda dikkate alınmasinda hukuka uygun bulmamaktadır. "Erciyes Üniversitesi Tip Fakültesi Çocuk Sağlı̆̆ ve Hastalikları Anabilim Dalında Doçent olarak görev yapan davacının, Rektörlügün ilan ettiği boş bulunan profesörlük kadrosu için yaptığ ... günlü başvuru hakkında herhangi bir işlem yapılmaması üzerine, Ögretim Üyeliğine Yükseltme ve Atama Yönetmeliği hükümleri uyarınca işlem yapılmast istemiyle ... gününde yaptığ ikinci başvuruya yanıt verilmeyerek zımnen reddine ilişkin işlemin iptali istemiyle açılan davayı süre aşımı nedeniyle reddeden" ilk derece mahkemesi kararının temyiz incelemesinde,

"Idari işlemler kimi zaman da, idarece yapılan duyurulardan sonra ilgili istekleri değerlendirilmek suretiyle halka işlemler oluşturulacağına göre bu tür davalarda süre durumunu farklı şekilde ele almak gerekir.

Bakılan uyuşmazlikta ise sonunda Rektör onaylyla kesinleşecek bir dizi işlemden oluşan zincir işlemlerin yapılması söz konusudur. Zinciri oluşturan sıra işlemlerin alınması için ilgili yönetmelikte öngörülen süreler, olası sürüncemelerin önüne geçilmesi amacıyla konulmuş olup idari dava süresine esas alınamazlar.

Bu durumda sürelerin geçtiği varsayllarak, başvurunun reddedildiği sonucuna varmak, idari işlem kuramı ile geliştirilmişs idare hukuku ilkeleriyle bağdaşmaz. Söz konusu süreler geçtikten sonra da halka işlemler oluşturulabilir. Kald ki profesör atamasının yönetim kurulu kararı ve rektör onayıyla gerçekleştiği de yasa kuralıdır. Bu durumda, yapılan ilanı izleyen başvuru sürecinden ve bir dizi işlemin alınmasından sonra oluşacak olan profesörlük atamasıyla ilgili kesin ve son işlemin oluşum süreci ve biçimi dışına çıkılarak; zincir işlemi oluşturan bazı ön işlemlerin alınışıyla ilgili sürelerin geçtiğinden söz edilip, idari işlemin oluştuğu varsayılarak, dava açılmadan önceki idari itiraz yoluna değinilerek dava süresinin dolduğu sonucuna varmaya hukuken olanakl değildir. Öte yandan, 2577 sayll Yasanın 10. maddesinde öngörülen şekilde bir müracaat ve susarak oluşan ret işleminin olayda gerçekleşip gerçekleşmediğinin, mahkemenin bu yolda yapacă̆ irdelemeden sonra değerlendirileceği de kuşkusuzdur. Açılanan nedenlerle, idare mahkemesi kararının bozulmasına karar verildi ${ }^{, 54}$.

${ }_{54}^{53}$ Danıştay 11.D., 09.05.2007, E.2007/3163, K.2007/4944, (yayımlanmamış karar).

54 Danıştay 8.D., 22.02.2000, E.1999/4726, K.2000/1621, Danıştay Dergisi, (www.danistay.gov.tr: 22.06.2008). 
İdari işlem teorisinde, belirli ve nihai bir sonucu doğurmak amaciyla birbirini takip eden ve tamamlayıcı bir dizi işlem" işlemlerin tamamlanabilmesi için belirli bir sürenin geçmesi eşyanın tabiatının gereğidir. Bu yön itibariyle Danıştay'ın kararı isabetlidir. Ancak, uygulamadaki kişisel tecrübelerimizden biliyoruz ki, özellikle akademik personel atamalarında çok uzun süreler geçmesine rağmen hala işlemin yapılmadığ ; idarenin olumlu ya da olumsuz bir cevap verme gereği bile duymadığı olaylar olabilmektedir. Bu da bir çok hak mahrumiyetine neden olabilmektedir. Bu nedenle, 2577 sayılı Yasanın 10. maddesinde öngörülen azami 6 aylık bekleme süresinden sonra dava açılabilmelidir.

\section{Mevcut Bir İdari İşlemin Kaldırılması veya Değiştirilmesine İlişkin Yapılan Başvurular}

İdari Yargılama Usulü Kanunun 11.maddesine göre, "ilgililer tarafindan idari dava açılmadan önce, idari işlemin kaldırılması, geri alınması değiştirilmesi veya yeni bir işlem yapılması üst makamdan, üst makam yoksa işlemi yapmış olan makamdan, idari dava açma süresi içinde istenebilir. Bu başvurma, işlemeye başlamış olan idari dava açma süresini durdurur. Altmış gün içinde bir cevap verilmezse istek reddedilmiş sayılır. İsteğin reddedilmesi veya reddedilmiş sayılması halinde dava açma süresi yeniden işlemeye başlar ve başvurma tarihine kadar geçmiş süre de hesaba kat1lir".

İdare tarafından tesis edilen bir işlemden sonra yapılan başvurular işlemeye başlayan dava açma süresini durdurur ${ }^{56}$. Başvurunun işlemeye başlayan dava açma süresini durdurabilmesi için 60 günlük dava açma süresi içinde yapılması gerekir ${ }^{57}$. Başvuru üzerine idare tarafindan bir cevap verilmesi halinde duran dava açma süresi kaldığ 1 yerden işlemeye devam eder. İdare başvuruyu belli bir süre zarfinda cevaplamak zorunda olup, mevzuatta öngörülen süre içinde başvuruyu cevaplamazsa ilgilinin istemi zımnen reddedilmiş sayılır. İşlemin tesisinden sonra işlemi tesis eden

55 Celal Erkut, İdari İşlemin Kimliği, Danıştay yayınları, Ankara, 1990, s.122; Bahtiyar Aky1lmaz, Ídare Hukuku, Sayram Yayınları, Konya, 2005, s.277.

56 Danıştay 12.D., 28.01.2005, E.2004/3660, K.2005/103, Danıştay Dergisi, S.110, s.344; Danıştay 11.D., 03.12.2002, E.2001/1635, K.2002/3906, Danıştay Kararları Dergisi, S.1,s.440; Danıştay 6.D., 02.11.1999, E.1999/5181, K.1999/5168, Danıştay Dergisi, S.103, s.605; Halil Kalabalık, İdari Yargılama Usulü Hukuku, 2.bası, Değiş̧im Yayınları, Sakarya, 2006, s.225.

57 "Dava açma süresi geçirildikten sonra, dava konusu yönetmeliğin değiştirilmesi istemiyle davalı idareye yapılan başvurunun, 2577 sayılı Kanunun 11. Maddesine göre dava açma süresini durdurmaz" Danıştay 5.D., 22.09.2003, E.2003/3144, K.2003/3551, Danıştay Kararları Dergisi, S.3, s.169; "İlk maaşının yatışı ile ek ders ödenmediğini anlayan davacının 60 günlük dava açma süresi içinde dava açması ya da idareye 11. madde uyarınca başvuru yapması gerekirken, dava açma süresi geçtikten sonra yaptığı idârî başvuru ile dava açma süresinin canlanmaz", Danıştay 11.D., 17.12.2007, E.2005/2183, K.2007/9780 (yayımlanmamış karar). 
makama yapılan bu başvurunun 60 gün içinde cevaplanmamasının zımni ret sebebi sayıldığg Danıştay kararlarında da vurgulamaktadır.

Danıştay, Müzik öğretmeni olan davacının 2001 yılı öğretmen alımı döneminde tercihleri arasına 42 (Konya) yazmasına rağmen 4 (A ğrı) olarak kodlaması nedeniyle Ağr1 iline atanması üzerine, 27.09.2001 tarihinde idareye başvurarak kodlama hatası olduğu ve atamasının düzeltilmesini istediği, ancak idarece bu konuda herhangi bir işlem tesis edilmemesi üzerine, davacının 09.01.2004 tarihinde yeniden idareye başvurarak 27.09.2001 sayılı başvurusuna cevap verilmesini istediği, isteğinin reddi işleminin iptali için 19.01.2004 tarihinde açtığı davada, Danıştay 12. Dairesi davacının atama işleminin kendisine tebliği üzerine anılan işlemin düzeltilmesi istemiyle 27.09.2001 tarihli başvurusundan itibaren 60 gün içinde idarece herhangi bir işlem tesis edilmemesi halinde isteğin zımnen reddedilmiş sayılacağı ve bu tarihten sonra 60 günlük dava açma süresinden, atama işlemin tebliği ile idareye başvuru arasında geçen sürenin düşüldükten sonra kalan süre içinde dava açılması gerekirken, bu süreler geçirildikten çok sonra yapılan başvuruya verilen cevap dava açma süresini yenilemeyeceğinden, bu cevap üzerine açılan davayı süre aşımı nedeniyle inceleme olanağı bulunmadığına karar vermiştir.

2577 sayıl1 Kanunun 11. maddesinde idarenin 60 gün içinde cevap vermemesi halinde talebin reddedilmiş sayılacağı düzenlenmiştir. Burada iki hususa değinmekte yarar vardır. Birincisi, 60 günlük cevap verme süresi geçtikten sonra cevap verilmesi halinde, bunun işlemeye başlamış olan süreye etkisi nasıl olacağı; İkincisi ise, bu süre içinde idarece verilen cevap kesin değilse dava açma süresi nasıl hesaplanacağı hususudur.

Danıştay'a göre, “2577 sayılı Yasanın 11.maddesi uyarınca yapılan başvuru üzerine altmış gün içerisinde yanıt verilmesi halinde istemin reddedilmiş sayılır, bu tarihten sonra verilen yanıt istemin reddine ilişkin olmayıp yeni bir işlem tesisine yönelik olması durumunda ise yeni bir hukuki sonuç yaratan bu işleme karşı süresi içerisinde dava açılabililir ${ }^{58, "}$ Danıştay, bir başka kararında, 2577 sayılı Yasanın 11. maddesi uyarınca idareye yapılan itirazın kabul edilerek, idarece yeni bir işlem tesis edilmesi halinde, ilgilinin bu yeni işleme karşı da aynı Yasanın 11. maddesinde öngörülen usulde itiraz edebileceği ve itirazın reddi üzerine bu karara karşı yasal süre içinde dava açabileceğini belirtmiştir ${ }^{59}$.

58 Danıştay 6.D., 20.04.199, E.1998/1839, K.1999/2054; Danıștay 5.D., 06.02.1992, E.1991/3142, K.1992/226, (www.danistay.gov.tr: 24.06.2008); Coşkun-Karyağd1, s.215.

${ }^{59}$ Danıştay 10.D., 10.04.2007, E.2005/9100, K.2007/1765, Danıştay Dergisi, S.117, s.290.; Danıştay bir kararında ise, "30.6.1999 tarihinde komiser yardımcılığına atanan ve aynı tarihte göreve başlayan davacının, 9.3.2000 tarihli kıdem listesinin tebliği üzerine 10.4.2000 tarihinde k1dem sıralamasının düzeltilmesi istemiyle 2577 sayılı Yasanın 11.maddesi uyarınca itirazda bulunduğu, bu başvurusunun reddine ilişkin 9.5.2000 tarihli işlem 16.5.2000 tarihinde kendine tebliğ edildiği halde kalan dava açma süresi içinde söz 
2577 sayılı Yasanın 10.maddesinde "altmış günlük süre içinde idarece verilen cevap kesin değilse ilgili bu cevab1, isteminin reddi sayarak dava açabileceği gibi, kesin cevabı da bekleyebilir. Bu takdirde dava açma süresi işlemez. Ancak, bekleme süresi başvuru tarihinden itibaren altı ayı geçemeyeceği” öngörülmüş olmasına rağmen, 11.maddede kesin olmayan cevaplar üzerine kesin cevabı bekleme imkanı düzenlenmemiştir. Danıştay göre, 2577 sayılı İdari Yargılama Usulü Kanunu'nun 11. maddesinde belirtilen cevaptan anlaşılması gereken "isteğin reddedilmesi veya reddedilmiş sayılması" hali olup; idarenin işleyiş̧iyle ilgili cevaplar dava açma süresinin hesaplanmasında esas alınamaz"60.

Fakat Danıştay'ın bazı kararlarında 11. maddenin 2.fikrasında öngörülen zımnî red durumunun hiç dikkate alınmadığı görülmektedir. Denizli Serbest Muhasebeci Mali Müşavirler Odası tarafından stajın iptali işlemine karş1, 16.01.2006 tarihinde Türkiye Serbest Muhasebeci ve Mali Müşavirler ve Yeminli Mali Müşavirler Odaları Birliğine (TÜRMOB) itiraz edilmiştir. Muhasebecilik Staj Yönetmeliğinin 24.maddesine göre, Oda Yönetim kurullarının bu konulardaki kararlarına karşı 15 gün için Birlik nezdinde itiraz edilebilir. Birliğin 60 gün içinde vereceği karar kesindir. Fakat, yapılan itiraza 60 gün içinde cevap verilmediği için davacı bunu zımnî red sayarak 12.05.2006 tarihinde Ankara İdare Mahkemesinde iptal davası açmıştır. Birlik yönetimi, savunmasında ilgili stajyerin yanında staj yaptığı Mali Müşavir ... hakkında da soruşturma yürütüldüğü, bu soruşturmanın neticelenmesinden sonra itirazın karara bağlanacağı, dolayısıyla ortada dava konusu olabilecek kesin ve yürütülmesi zorunlu bir işlem olmadığını savunmuştur.

Davacı, hem dava dilekçesinde ve hem de temyiz dilekçesinde açıkça 60 gün içinde cevap verilmediğini iddia etmesine rağmen bu iddia dikkate alınmamıştır. 2577 sayılı Yasanın 11.maddesi ve ilgili staj yönetmeliğinin 24.maddesindeki "Birlik nezdinde yapılacak itirazların 60 gün içinde karara bağlanacağı" yönündeki açık hükme rağmen gerek ilk derece mahkemesi ve gerekse Danıştay 8.Dairesi tarafından hiç dikkate alınmamıştı́r ${ }^{61}$. Diğer taraftan, Danıştay TURMOB'a itirazı zorunlu başvuru olarak

konusu işlemin iptali istemiyle dava açmadığı, bu süreler geçirildikten çok sonra aynı kıdem ve atama tarihini ihtiva eden 14.3.2002 tarihli kıdem sıralamasını gösterir listede mezuniyet tarihinin hatalı olduğunu öne sürerek 20.5.2002 tarihinde yaptı̆̆ başvurunun da yukarıda anılan 11.madde hükmü uyarınca yeni bir dava açma süresi ihya etmeyeceği açı olup İdare Mahkemesince bu hususlar gözetilerek bakılan davanın süre aşımı nedeniyle reddi gerekirken işin esası hakkında karar verilmesinde hukuki isabet görülmemiştir" diyerek 11. madde uyarınca iki kez başvuru yapma yolunu kapatmıştır. Burada yeni bir hukuki durumun varlığını da kabul etmemiştir. Danıştay 12.D., 21.12.2004, E.2003/2321, K.2004/4188, Danıștay Dergisi, S.110, s.346.

${ }^{60}$ Danıştay İdari Dava Daireleri Kurulu, 23.06.2006, E.2006/133, K.2006/763, Danıştay Dergisi, S.114, s.85.

${ }^{61}$ Danıştay 8.D., E.2007/7072, K.2007/7510 (Yayınlanmamış karar). 
yorumlamaktadır. Aslında yukarıda belirtildiği üzere, burada ihtiyari başvuru vardir.

Yine Danıştay'a göre, kendi yasasında özel itiraz usulü ve süresi öngörülmesi halinde yapılan itiraz 2577 sayılı Yasanın 11. maddesi kapsamında kabul edilemez ve dava açma süresinin işletilmesine esas alinamaz $^{62}$.

\section{Zorunlu İdari Başvurular}

Yasama organı, bazı idari başvuruların yapılmasını zorunlu kılmıştır ${ }^{63}$. Örneğin, 4734 sayılı Kamu İhale Kanununa göre, "itirazen şikâyet, dava açılması öncesinde kullanılması zorunlu bir başvuru yoludur" (m.56/6). Diğer bir ifade ile ilgililer ihale işlemlerine karşı dava açmadan önce Kamu İhale Kurumuna itirazen şikayet başvurusu yapılmak zorundadır. Yine 2577 sayılı İdari Yargılama Usulü Kanunu'na göre, “idari eylemlerden hakları ihlal edilmiş olanların idari dava açmadan önce, bu eylemleri yazılı bildirim üzerine veya başka suretle öğrendikleri tarihten itibaren bir y1l ve her halde eylem tarihinden itibaren beş yıl içinde ilgili idareye başvurarak haklarının yerine getirilmesini istemeleri gereklidir" (m.13). İdari eylemden kaynaklanan hak ihlallerinden dolayı ön $\operatorname{karar}^{64}$ alma amaciyla yapılan idari

62 “... DMK 117. ve 118. maddelerdeki düzenlemenin yanlızca sicilleri kapsayan "özel" niteliğinden dolayı, 118. madde uyarınca yapılan itirazın 2577 sayılı Yasanın 11. maddesi kapsamında düşünülmesine ve bu itirazın gerek tabi olacağ 1 süre, gerek dava süresine etkisi yönlerinden anılan Yasanın 11. maddesine göre değerlendirilmesine olanak yoktur. Bir başka anlatımla, kendisine 117. madde uyarınca tebligat yapılan ilgilinin tebligat konusu işleme karşı doğrudan doğruya iptal davası açmayarak itiraz yoluna başvurması halinde 60 günlük dava süresi itirazının reddine ilişkin işlemin tebliğ tarihinden, itirazı cevap verilmemek suretiyle reddedilmişse iki aylık cevap süresinin bittiği tarihten itibaren işlemeye başlayacak olup itiraza konu işlemin tebliğ tarihi ile itiraz tarihi arasında geçen sürenin dava süresinin hesabında dikkate alınmasına, konunun "özel" hükümlerle düzenlenmiş olması nedeniyle, yasal olanak bulunmamaktadır.” Danıştay 8.D., 12.03.2003, E.2002/1541, K.2003/1122, Danıştay Kararları Dergisi, S.2, s.289; Danıştay 10.D., 14.11.2002, E.2000/260, K.2002/4360, Danıştay Kararları Dergisi, S.1, s.411.

${ }^{63}$ Zorunlu idari başvuru ile ilgili bazı örnek düzenlemeler: 195 Sayılı Basın İlan Kurumu Teşkiline Dair Kanunun 38. maddesi, 1136 Sayılı Avukatlık Kanununun 7,8,20, 64, 70,74, 142, 153, 157. maddeleri, 4458 Sayılı Gümrük Kanunu 242,243. maddeleri, 2762 Sayılı Vakıflar Kanunun 33. maddesi, 213 Sayılı Vergi Usul Kanunu 124. maddesi, 4081 Say1lı Çitçi Malları Koruma Kanunu 8/3, 10. maddeleri, 4109 Sayılı Asker Ailelerinden Muhtaç Olanlara Yardım Hakkında Kanunun 7. maddesi, 5590 Sayılı Kanunun 17/j, 43/1, 56. maddelerinde yer alan hükümler, 6961 Sayılı Ziraat Odaları ve Ziraat Odaları Birliği Kanunu 5 ve 10/d maddeleri, 5442 Sayılı İl İdaresi Kanunu 2. maddesinde yer alan hükümler, Ayrıca Danıştay yerleşik içtihatlarına göre 2547 Sayılı Yüksek Öğretim Kanunu 54/e maddesi hükümleri zorunlu idari başvuru gerektiren durumlardan bazılarıdır. Zorunlu idârî başvuruların dava açma süresine etkileri ile ilgili olarak bkz. Gürsel Kaplan, Ídari Yargıda Dava Açma Süreleri, Ankara 2007, s.266 vd.

${ }^{64}$ Şeref Gözübüyük - Turgut Tan, İdare Hukuku, İdari Yargılama Hukuku, Cilt.2, Ankara, 1999, s. 897; A. Şeref Gözübüyük, Yönetsel Yargı, 13.bası, Ankara, 1999, s.267. 
başvuru, idari dava açma süresini başlatıcı bir etkiye sahip olması nedeniyle uyuşmazlık doğuran bir işlemdir. Danıştay Kararlarına bakıldığında idârî eylemlerden doğan başvurularla ilgili oldukça çok sayıda karar bulunmaktadır ${ }^{65}$. Danıştay 10. Dairesi bir kararında, Davacıların 17 Ağustos 1999 tarihinde meydana gelen deprem dolayısıyla uğradıkları zararın, sadece idârî işlem sebebiyle değil, aynı zamanda idarenin önlem alma ve denetim görevini de yerine getirmemesinden, başka bir ifadeyle hareketsiz kalmasından kaynaklandığı göz önünde bulundurulduğunda, bakılmakta olan davada, dava açma süresinin 2577 sayılı Yasanın 13. maddesi uyarınca hesaplanması gerektiğine karar vermiştir ${ }^{66}$. Ön karar almadan açılan davada idari merci tecavüzü ${ }^{67}$ söz konusu olacaktır. Bu durumda, mahkeme, idari merci tecavüzüne karar vererek dava dilekçesini idari eylemden doğan zarardan sorumlu olan ilgili idareye gönderir ${ }^{68}$.

65 Danıştay 10.D., 12.03.2007, E.2005/896, K.2007/899, Danıştay Dergisi, S.116, s.322 ; "İdari eylem ve işlemlerden doğan zararın ödenmesi isteminin 2577 sayılı Yasanın 13. maddesinde öngörülen süre içinde dava konusu edilmesi gerektiği, davanın görüldüğü aşamada bilirkişi raporundan öğrenilen zararın fazlaya ilişkin kısmının bu süreler geçtikten sonra dava konusu edilemeyeceği hakkında", Danıştay 8.D., 07.10.2003, E.2003/590, K.2003/3845, Danıştay Kararları Dergisi, S.3, s.257; Danıştay 10.D., 02.11.1999, E.1999/1746, K.1999/5376, Danıştay Dergisi, S.103, s.857.

66 "Davacının ikamet ettiği lojmanın yıkılması nedeniyle kızının vefat etmesi ve eşyalarının zarara uğraması nedeniyle açılan tazminat davasında; Sakarya İdare Mahkemesince, uyuşmazlığın düzenleyici işlem olan imar planlarının usulüne uygun yapılmamasından kaynaklandığ itibaren 60 gün içinde dava açılabileceği yada 11. maddeye göre başvuru yapılacağ 1 , bu tarih geçtikten sonra açılan davayı süre aşımı nedeniyle reddi üzerine, Danıştay 10. Dairesince, tam yargı davaları için 2577 sayılı Yasanın 13. maddesinin özel düzenleme getirdiği, davanın açılma sebebi idârî tasarruf olan idârî işlem gibi gözükse de asıl, dava açılma sebebinin bir idârî eylem olduğu ve idârî eylemden kaynaklanan zararların tazmininde ise özel süre öngörüldüğü için, davayı süre aşımı nedeniyle reddeden anılan mahkeme kararı bu yönden bozulmuştur". Danıştay 10.D., 28.05.2007, E.2005/9126, K.2007/3069 , Danıştay Dergisi, S.117, s.294; Danıştay 11.D., 30.04.2004, E.2001/4552, K.2004/2026, Danıştay Kararları Dergisi, S.5, s.313; Danıştay 6.D., 12.04.2004, E.2004/1477, K.2004/2115, Danıştay Kararları Dergisi, S.5, s.188. Benzer bir başka kararda 10. Daire, Başvurduğu hastanede, kendisine acilen hemodiyaliz tedavisi görmesi gerektiği yolunda rapor verilen ve bunun üzerine 8 ay tedavi gören davacının, bu teşhisin hatalı olduğunun anlaşıldığından bahisle, uğranılan zararın tazmini istemiyle açtığı davada; idârî eylemden kaynaklanan zararın tazmini davası olduğundan; 2577 sayılı Yasa'nın 13. maddesindeki 1 yıllık süreye tabi olduğu, zararın idârî işlemden kaynaklandığından bahisle davanın süre yönünden reddine ilişkin kararda hukuki isabet bulunmadığına karar vermiştir. Danıştay 10.D., 12.03.2007, E.2005/896, K.2007/899, Danuştay Dergisi, S.116, s.321.

${ }^{67}$ Selami Demirkol- Zuhal Bereket, İdari Yargıda Dava Açma ve Davaların Takip Usulü, Ankara, 1998, s.84.; Gözübüyük, Yönetsel Yargl, s.478.

${ }^{68}$ Danıştay 10.D., 12.11.2001, E.2000/92, K.2001/3861, Bu konudaki emsal yargı kararları için bkz. Yakup Bal - Mustafa Karabulut - Yahya Şahin, İdari Yargılama Usulü ile İlgili Danıştay 10. Dairesinin Seçilmiş Kararları, Ankara, 2003, s.510 vd. 
Zorunlu idari başvurular, idari eylemlerde olduğu gibi dava açma süresini başlatabileceği gibi, dava açma süresini durdurucu etkiye de sahip olabilir. Zorunlu idari başvurunun hiç yapılmaması halinde, mevzuatta öngörülen süre geçirildikten sonra zorunlu idari başvuru yoluna gidilemez. Süre geçtikten sonra yapılan idari başvurular etkili idari başvuru olma özelliğini kaybeder, dava açma hakkı kullanılamaz ${ }^{69}$ ve dava açma hakkı düşer $^{70}$. Zorunlu idari başvuru yapılmadan açılan davalarda ise, ilgili mahkemesinde dava dosyası hakkında idari merci tecavüzüne ${ }^{71}$ karar verilir ve dava dilekçesi ilgili merciiye tevdi edilir. Ancak, bazen yasalarda zorunlu idârî başvuru yolu öngörülmediği halde mahkemelerce zorunlu idârî başvuru yolu varmış kabul edilerek karar verilebilmektedir. Nitekim Danıştay bir uyuşmazlıkta, Baro yönetim kurullarının baro levhasından silme kararları, kesin ve yürütülmesi zorunlu işlem niteliğinde olduğundan, dosyanın Türkiye Barolar Birliği'ne tevdiine karar veren idare mahkemesi kararında isabet görülmediğine karar vermiş ve idare mahkemesi kararını bozmuştur ${ }^{72}$.

Kimi bazı durumlarda ise, mevzuat bireylere belirli bir hak talebi için yapılması zorunlu başvuru yolları getirebilir. Bireyler kendilerine tanınan süre içinde bu idârî başvuru yapmadıkları takdirde başvurunun tanıdığ haklardan yararlanamazlar. Başvuru süresinden sonra yapılan başvurular ise etkili idârî başvuru olmaktan çıkar. Nitekim Danıştay bir kararında, "Dava dosyası ile Dairemize intikal eden aynı nitelikteki uyuşmazlıklarla ilgili dava dosyalarinda yer alan bilgi ve belgelerin birlikte incelenmesinden, Erzurum ve çevresinde 25-28 Mart 2004 tarihlerinde meydana gelen depremlerde ilk kesin hasar tespit listelerinin 14.4.2004- 17.5.2004 tarihleri arasinda mahallinde ilan edildiği, 12.4.2004- 10.6.2004 tarihleri arasinda da ilgililere hak sahipliği için 2 aylık talep ve taahü̈tname verme süresi tanındiğ , davacının belirlenen süreler içinde talep ve taahhütname vermeden, taşınmazın hasarlı olduğunu adli yargıda tespit ettirdikten sonra idarece yapilan hasar tespitine ilişkin işleminin hatalı olduğundan ve kendisinin de hak sahibi kabul edilmesi gerektiğinden bahisle adli yargl yerinde yaptırılan tesbite göre hak sahibi sayılması amacıla idareye yaptığ başvurunun reddine iliş̧kin işlemin iptali istemiyle davanın açıldiğ anlaşılmaktadır. Bu durumda, davacının yukarıda hükümlerine yer verilen

\footnotetext{
${ }^{69}$ Yildırım, s.200.

${ }^{70}$ Yenice - Esin, s.248.

${ }^{71}$ Gözübüyük - Dinçer, s. 398; Yıldırım, s.202; Kalabalık, s.271; İbrahim Topuz - Kadir Özkaya, İdari Yargılama Usulü Kanunu, Ankara, 2002, s. 376; Nuri Alan, "İptal Davalarının Ön ve Esastan Kabul Şartı", Danıştay Dergisi, Yı1:13, S.50-51, 1983, s.30; Turgut Candan, Açıklamalı İdari Yargılama Usul Kanunu, 2.bası, Ankara, 2006, s. 558; Danıştay 13.D., 30.11.2005, E.2005/6393, K.2005/5716 (www.danistay.gov.tr: 05.05.2008); Danıștay 13.D., 28.06.2006, E.2006/1176, K.2006/2759, (www.danistay.gov.tr: 05.05.2008).

72 Danıştay 12.D., 13.10.2003, E.2003/380, K.2003/2077, Danıştay Kararları Dergisi, S.3, s.342.
} 
mevzuatta öngörülen usule uygun olarak yasal süreler içerisinde idareye zorunlu olarak yapılması gereken başvuruların yapmadan, doğrudan adli yargı tespit kararı üzerine idarece yapılan hasar tesbitine ilişkin işleminin hatalı olduğundan bahisle adli yargl yerinde yaptırllan tesbite göre hak sahibi sayllması amacıyla idareye yaptığı başvuru sonucu tesis edilen ve adli yargl yerinde yaptırılan bilirkişi incelemesi sonucu düzenlenen hasar tesbit raporuna göre idarece yapılacak bir işlem olmadiğl yolundaki işlemde mevzuata aykırllık bulunmadı̆̆ından, dava konusu işlemin iptaline ilişkin idare mahkemesi kararında usul ve mevzuata uyarlı görülmemiştir." diyerek bu husus vurgulanmıştır ${ }^{73}$.

Sonuç olarak, ilgili mevzuatta bir hak olarak düzenlenen ve ilgililerin isteğine bırakılan bazı idari başvurular, Danıştay tarafından dava hakkının kaybı şeklinde sonuçlanabilecek zorunlu bir idari başvuru olarak yorumlanabilmektedir.

\section{V. İsteğe Bağlı İdari Başvurular}

Kanun koyucu, bazı idari başvuruları ilgili kişilerin isteğine bırakmıştır. Kişiler, isteklerini veya şikayetlerini idari makamlara iletip iletmemede serbesttirler. Bir başka ifade ile, kişiler haklarını veya menfaatlerini ihlal eden idari tasarruflara karşı önce idari başvuru yapabilecekleri gibi, idari başvuru yapmadan doğrudan doğruya yargı merciine de başvurabilir. Bir başvurunun isteğe bağlı olup olmadığı ilgili mevzuat hükmünden anlaşılabilir. Bu tür isteğe bağlı idari başvuru hakkı tanıyan kanun, tüzük veya yönetmeliklerin büyük bir kısmı "itiraz edilebilir", "isteyebilir" biçiminde ifadeleri ihtiva eder. Ancak, isteğe bağlı idari başvuruların ilgili mevzuatta mutlaka bu şekilde bulunması şart değildir. Yukarıda açıklandığı üzere, ilgili mevzuatta idari başvuru yolu açıkça yasaklanmayan hallerde ve de zorunlu idari başvuru öngörülmeyen durumlarda özel mevzuat hükümlerinin yanında İdari Yargılama Usulü Kanunu'nun 10. ve 11. maddeleri çerçevesinde idari başvuru yapılabilir.

İsteğe bağlı idari başvurular ise, hukuksal sonuçları açısından etkili idari başvurulardandır. İsteğe bağlı idari başvuru, süresi içinde yapıldığı takdirde, işlemeye başlayan dava açma süresini durdurur ${ }^{74}$. Nitekim, Danıştay bir kararında da Devlete Ait Taşınmaz Mal Satış, Trampa, Kiraya Verme, Mülkiyetin Gayri Ayni Hak Tesisi, Ecrimisil ve Tahliye Yönetmeliğinin 80. maddesinde kendisine ecrimisil ${ }^{75}$ ihbarnamesi gönderilen kişinin bu ihbarnameye karşı 30 gün içinde itiraz başvurusunda

${ }^{73}$ Danıştay 11.D., 10.04.2006, E.2006/232, K.2006/1710, Danıștay Dergisi, S.114, s.309.

${ }^{74}$ Danıştay İdari Dava Daireleri Kurulu, 16.06.2005, E.2003/428, K.2005/2175, Danıştay Dergisi, S.111, s.79; Danıştay 6.D., 12.05.2004, E.2004/492, K.2004/2973, Danıştay Kararları Dergisi, S.6, s.171.

75 Kamu mallarında ecrimisil konusunda bkz: Yasin Sezer, "Kamu Mallarında Ecrimisil", Danıştay Dergisi, S.108, 2004, s.5-23. 
bulunabileceği ve bu başvurunun ise, 2577 sayılı Yasa'nın 11. maddesinde düzenlenen ihtiyari başvuru yolu olduğu, dava açma süresini durduracağı ve verilen cevabın tebliği üzerine dava açma süresinin yeniden işlemeye başlayacağı vurgulanmıştır ${ }^{76}$. Aynı Daire bir başka kararında aynı şekilde bu itiraz yolunun ihtiyari itiraz yolu olduğunu vurgulamış ve ecrimisil tahakkuk ve tahsilini düzenleyen yönetmeliğin 80 . maddesinde yer alan ihtiyari itiraz yoluna başvurulmasının, 2577 sayılı Yasanın 11. maddesinde öngörülen itiraz yolunun dava açma süresi yönünden doğurduğu sonucu doğuracağı, dava açma süresi dolduktan sonra idarece cevap verilmesinin yeni bir dava açma süresi doğurmayacağına hükmetmiştir ${ }^{7 \dagger}$. Burada idârî başvurunun zımnen reddi üzerine idarece cevap verilmiş olmasının 2577 sayılı Yasanın 10. maddesindeki imkanı tanımadığı vurgulanmak istenmiştir.

Bazı yasalarda isteğe bağlı idari başvuru olarak düzenlenen -bazılarına yukarıda değinildi- idari başvurular, Danıştay tarafından zorunlu başvuru yolu olarak kabul edilebilmektedir. Baro Disiplin Kurulu kararlarına karşı Cumhuriyet Savcısının Avukatlık Kanunu'nun 157. maddesi uyarınca yapmış olduğu itiraz isteğe bağlı bir idari başvuru türü iken Danıştay bir kararında, Baro kararına karşı ilgilinin Türkiye Barolar Birliği Disiplin Kuruluna itiraz edilmesi ve kararın buradan geçip kesinleşmesi üzerine idari yargıya başvurulması gerektiğinden, davada idari merci tecavüzü nedeniyle dosyanın Türkiye Barolar Birliğine gönderilmesi gerektiğine karar vermiştir $^{78}$. Ancak, Danıştay'ın bu kararına katılmak mümkün değildir. Zira, yasa metninden de açıkça anlaşılacağ 1 üzere, burada gerek Cumhuriyet Savcısına gerekse ilgili kişiye isteğe bağlı bir idari başvuru yolu öngörülmüş̧ür. İlgili kişi dilerse isteğe bağlı olarak Türkiye Barolar Birliği Disiplin Kurulu'na itiraz edebilir ya da bu başvuru sonucunda her hangi bir sonuç elde edemeyeceğini düşünüyorsa doğrudan idari yargı yerinde dava açabilmelidir.

${ }^{76}$ Danıştay 10.D., 10.04.2007, E.2005/9100, K.2007/1765, Danıştay Dergisi, S.117, s.290.

77 “...Belirtilen nedenlerle 30.8.2003 tarihinde tebliğ edilen ecrimisil ihbarnamesine karşı 3.10.2003 tarihinde itiraz edilmekle işlemeye başlamış olan dava açma süresinin 34.gün durduğu, idare tarafından 60 gün içinde cevap verilmeyerek 3.12.2003 tarihinde itirazın zımmen reddedilmiş sayılacağı ve 4.12.2003 tarihinde tekrar işlemeye başlayan dava açma süresinin geriye kalan 26. günün sonu olan 29.12.2003 tarihinde sona ereceği anlaşılmıştır. Yukarıda belirtildiği şekilde dava açılmadan dava açma süresi geçirildikten sonra idarece 20.1.2004 tarihinde itirazın reddi yolunda işlem tesis edilmiş olmasının yeni bir dava açma süresi kazandırmayacağı ve dolayısıyla davacı tarafından 22.3.2004 tarihinde açılan davanın süresinde olmadığı tartışmasızdır.” Danıştay 10.D., 31.01.2007, E.2004/13105, K.2007/258, Danıştay Dergisi, S.115, s.346.; Ecirimisil düzeltme ihbarnamesi, bir önceki ecrimisil ihbarnamesi işlemini ortadan kaldıran veya geri alan bir işlem niteliğini taşımadığından ecrimisil ihbarnemesinin kesin ve yürütülebilir niteliğini kaybetmediği hakkında Danıştay 10.D., 26.09.2005, E.2002/5410, K.2005/5506, Danıştay Dergisi, S.112, s.312.

78 Danıştay 8.D., 19.02.1997, E.1995/1883, K.1997/579, Danıştay Dergisi, S.94, s.484; Danıştay 8. D., 10.3.1987, E.1987/23 K.1987/114 (www.danistay.gov.tr: 28.06.2008). 
İsteğe bağlı idari başvuru yapan kişiler, 60 gün içinde idarenin cevap vermesini beklemek zorunda değildirler. Danıştay’a göre, “...Yükseköğretim Kurumları Yönetici, Öğretim Elemanı ve Memurları Disiplin Yönetmeliğinin ....47. maddesinde belirtilen itiraz yoluna başvurulması zorunlu bir idari prosedür olmadiğından bu yola başvurulmasının idari işlemin kesinlik kazanmasını engellemeyeceği, itiraz yoluna başvuran ilgilinin aynı zamanda dava açma hakkını da kullanabileceği açık olup buna göre davacının iki yıl kademe ilerlemesinin durdurulmast cezast ile cezalandırllması ve bu cezanin aylığından 1/4 oranında kesinti yapılması suretiyle uygulanması yolundaki dava konusu işlemin hukuki sonuçları gözönüne alındığında bu işlemin kesin bir işlem olduğu ve dolayısiyla iptal davasina konu edilebileceği anlaşıldı̆̆ından, idare mahkemesince davanın esası incelenerek karar verilmesi gerekirken, dava konusu işlemin kesin bir işlem olmadı̆̆ından bahisle davanın reddine karar verilmesinde hukuki isabet görülmemiştir "79.

\section{Anayasa Mahkemesinin İptal Kararı Üzerine Yapılan İdari} Başvurular

Anayasa Mahkemesi'nce ${ }^{80}$ Kanunların, KHK'ların, Anayasa Değişikliği ve Meclis İç Tüzüğü değişikliklerinin Anayasa'ya uygunluğu denetlenmektedir. Anayasa Mahkemesi kararları kural olarak geçmişe yürümez. (1982 AY. m. 153 ) Ancak, Anayasa Mahkemesi'nce bir kanun hakkında verilen iptal hükmü ile birlikte hukuk aleminde de bir takım değişiklikler oluşmaktadır. Yeni durum bireylere iptal edilen hükümden önce sahip olduğu bazı hakları idarelerden talep etme yetkisi sağlayabilmektedir. İşte bireyler sahip oldukları bir takım hakları idârî başvuru yolu ile talep edecekler ve bu taleplerinin reddi halinde, ilgili idare mahkemesine iptal davası açabileceklerdir. Burada şu sorun ortaya çıkmaktadır. İlgilinin Anayasa'ya aykırı kanun hükmü ile bir hakkının ihlal edilmiş olması halinde bu ihlalin giderilmesi için ihlal anında idareye başvurup idarece tesis edilen işlem üzerine idârî yargı yerine dava açmamış olması ilgilisi açısında bir hak kaybına neden olacak mıdır? Danıştay'ın bu konudaki içtihatları ilgililerin haklarının korunması yönündedir. Nitekim İdari Dava Daireleri bir kararında, davacının Anayasa Mahkemesi Kararının doğurduğu yeni hukuki sonuçlardan yararlanmak amacıyla, 2577 sayılı Yasanın 10. maddesine göre idareye başvurabileceği ve bu istemin reddi üzerine açılan davanın süresinde olduğunu belirtmiştir ${ }^{81}$.

Benzer bir görüş, Danıştay 2. Dairesi tarafından da kabul edilmiştir. 2. Daire bir kararında, Anayasa Mahkemesi'nce, ilgili yıl bütçe kanununun

${ }^{79}$ Danıştay 12.D., E.2003/380, K.2003/2077, Danıştay Kararlar Dergisi, S.3, 2004, s.342.

80 Yavuz Atar, Türk Anayasa Hukuku, 3. bas1, Konya, 2005, s.293; Mustafa Erdoğan, Anayasa Hukuku, 3.bas1, Ankara 2005, s.294 vd.

81 Danıştay İdari Dava Daireleri Kurulu, 08.06.2006, E.2006/231, K.2006/542, Danıştay Dergisi, S.114, s.79. 
konuya ilişkin maddesinin iptalinden sonra davacının sürekli görev yolluğunun ödenmesi için yaptığı başvurusunun reddine ilişkin işleme karşı açtığ 1 davanın süresinde olduğunun kabulü gerektiğine hükmetmiştir ${ }^{82}$.

Danıştay bir başka kararında ise, resen emekliye sevk edilen bir kişinin resen emekliye sevk işleminin dayanağı olan yasa kuralının, Anayasaya aykırılığının ileri sürülmesi, Anayasanın geçiçi 15. maddesinin son fikrasınca yasak olan ve bu nedenle Anayasa'ya aykırılığı ileri sürülemeyen işlemin anılan fikranın 17.10.2001 tarihinde yürürlükten kaldırılması üzerine, bu tarihten itibaren idareye yapılan başvuru üzerine verilen ret cevabı üzerine açılan davanın süresinde olduğuna karar vermiştir ${ }^{83}$. Danıştay bu kararında ilgilinin idârî başvuru yolunu kullanmasının ilgilisine dava hakkı tanımayacağına ilişkin sürede geçen zamanı dikkate almamıştır. İdari başvurunun dava açma hakkı tanınmasından sonra yeniden yapılabileceğini kabul etmiştir.

\section{Düzenleyici İşlemin İptali Üzerine Yapılan İdari Başvurular}

Danıştay'a göre, "İdare Hukuku ilkelerine göre, iptal kararları, iptali istenilen işlemi tesis edildiği tarih itibariyle ortadan kaldırarak, o işlemin tesisinden önceki hukuki durumu ortaya koyar. Bir genel düzenleyici işlemin iptal edilmesi durumunda, verilen yargı kararının, sadece o davayı açanı değil, bu genel düzenleyici işlem ile ilgili diğer kişileri de etkileyeceği kuşkusuzdur. İptal kararı ile bu düzenleyici işleme dayanılarak yapılan işlemlerin doğurduğu etki ve sonuçlar ortadan kalkar. Bu nedenle iptal edilen bir düzenleyici işlemden dolayı, menfaati ihlal edilen veya kişisel hakkı etkilenen kişinin, verilen iptal kararının doğurduğu sonuçlardan yararlanmak amacıyla idareye başvurabileceği tabiidir" ${ }^{\prime 4}$.

Danıştay 6. Dairesi, uygulama işlemi niteliğinde olan kamulaştırma işlemi üzerine, anılan işlemin dayanağı düzenleyici işlem niteliğindeki imar planlarının iptali istemiyle açılan davada, uygulama işlemine karşı açılan dava süreaşımı yönünden reddedildiğinden, imar planlarının iptaline ilişkin işlemin bu aşamada incelenemeyeceğine karar vermiştir ${ }^{85}$. Danıştay'ın bu kararından da anlaşılacağı üzere düzenleyici işlemin iptali uygulama işlemiyle birlikte istenebilmesi için uygulama işleminin iptali için yasal süresi içinde dava açılması gerekir.

Danıştay 10 Dairesince verilen bir kararda da, dayanak oluşturan düzenleyici işlemin iptali sonrasında eksik yapılan ödemenin iadesi için 2577 sayılı Yasanın 10. maddesi uyarınca yapılan başvuru üzerine açılan

\footnotetext{
${ }^{82}$ Danıştay 2.,D., 17.12.2004, E. 2004/2513, K.2004/1601, Danıştay Dergisi, S.109, s.107.

83 Danıştay İdari Dava Daireleri Kurulu, 19.04.2007, E.2005/2988, K.2007/555, Danıştay Dergisi, S.116, s.55.

${ }^{84}$ Danıştay 11.D., 08.05.2006, E.2006/550, K.2006/2142, Danıştay Dergisi, S.113, s.356.

${ }^{85}$ Danıştay 6.D., 22.09.2006, E.2004/3697, K.2006/4213, Danıştay Dergisi, S.114, s. 207.
} 
davayı süre yönünden reddeden idare mahkemesi kararında yasaya uyarlık bulunmadığına hükmedilmiştir ${ }^{86}$.

Danıştay 11. Dairesince, ek ödemelere ilişkin düzenleyici işlemin iptal edilmesi üzerine, iptal edilen bir düzenleyici işlemden dolayı, kişisel hakkı etkilenen kişinin, iptal kararının doğurduğu sonuçlardan yararlanmak üzere idareye yaptığı başvurunun 2577 sayılı Kanun'un 10. maddesi kapsamında yapılan bir başvuru olarak kabulü gerektiğine karar verilmiştir ${ }^{87}$. Aynı şekilde 11. Daire bir başka kararında da, Sözleşmeli personel çalıştırılmasına ilişkin esasları belirleyen 7/15754 sayılı Bakanlar Kurulu Kararı'nın 7/1. maddesinin iptali üzerine, daha önce emekli olmasına karşın anılan düzenleyici işlem nedeniyle iş sonu tazminatı ödenmeyen davacının, iptal kararının doğurduğu hukuki durumdan yararlanmak amacıyla yaptığı başvurunun, İdari Yargılama Usulü Kanunu'nun 10. maddesi kapsamında bir başvuru olduğunun kabulü gerektiğine hükmetmiştir ${ }^{88}$. Aynı Daire, bir başka kararında iptal edilen düzenleyici işlem üzerine yapılan başvuruya verilen cevabın dava konusu edileceği ve başvuruda yer almayan hususların ise açılan dava ile istenemeyeceğine karar vermiştir ${ }^{89}$.

Danıştay 12. Dairesi ise, genel düzenleyici işlem ve bu işlemin kendisine uygulanmaması istemiyle açılacak olan davalarla ilgili olarak bir kararında "davacının genel düzenleyici işlem olan genelgenin iptali için; genelgenin kendisine tebliğinden sonraki altmış gün içinde dava açılmadığı

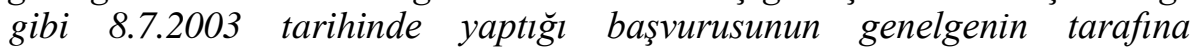
uygulanması istemi olarak kabul edilmesi halinde dahi bireysel işlemin tesis edilme tarihi; cevap verilmemek suretiyle davacının isteminin reddi tarihi olacaktır ki bu durumda dahi davanın süresinde açılmadĭ̆ı anlaşılmaktadır. Yani, davacinın 8.7.2003 tarihli dilekçesinden sonraki 60 gün içerisinde istemine cevap verilmemesini olumsuz işlem olarak kabul edip, 7.9.2003 tarihinden itibaren 60 gün içerisinde en geç 6.11.2003 tarihinde olumsuz bireysel işlemle ile birlikte genel düzenleyici işleme karşı dava açması gerekirken; 29.3.2004 tarihinde dava açmış olması karşısında açılan

${ }^{86}$ Danıştay 10.D., 06.04.2005, E.2003/1545, K.2005/1547, Danıştay Dergisi, S.110, s.298.

${ }^{87}$ Danıstay İdari Dava Daireleri Kurulu, 05.05.2005, E.2005/470, K.2005/1158, Danıștay Dergisi, S.111, s.82.

${ }^{88}$ Danıştay 11.D., 27.01.2006, E.2003/3204, K.2006/213, Danıștay Dergisi, S.113, s.344.

89 “..Bu durumda, Danıştay Onbirinci Dairesince iptal edilen düzenleyici işleme dayanılarak davalı idareye yapılan başvurunun, sadece 80 saate kadar tutulan nöbetler için için ödenmeyen ek ödeme tutarlarının tazmini istemini içerdiği, ret işleminin bu isteme ilişkin olduğu ve davacının raporlu olduğu dönemlere ilişkin ek ödeme yapılması isteminde bulunmadığı ve böyle bir istemin reddinin söz konusu olmadığı anlaşıldığından, 2577 sayılı İdari Yargılama Usulü Kanununun 10. maddesi hükmü uyarınca raporlu olduğu dönemlere ilişkin işlem tesis ettirmeksizin açılan davanın bu kısmının incelenmeksizin reddedilmesi gerekirken, işin esasına girilerek davacının raporlu olduğu dönemlere ilişkin olarak da ek ödeme tutarının tazminine dair verilen kararda hukuka uyarlık bulunmamıştır." Danıştay 11.D., 09.05.2007, E.2007/3163, K.2007/, (yayımlanmamış karar). 
davanın süresinde açılmadı̆̆ ve davanın süre aşımı yönünden reddi gerektiği açıktır" demiştir ${ }^{90}$.

Danıştay İdari Dava Daireleri ise, zımni ret şeklinde gerçekleşen uygulama işleminden sonra, bu işlem dava konusu edilmeksizin, düzenleyici işleme karşı açılan davanın, uygulama işlemine karşı öngörülen dava açma süresi içerisinde bulunması sebebiyle, davanın süre aşımı nedeniyle reddine ilişkin Daire kararında hukuki isabet görülmediğine hükmetmiştir ${ }^{91}$.

\section{SONUÇ}

Anayasanın 36.maddesi gereğince, herkes, meşru vasıta ve yollardan faydalanmak suretiyle yargı mercileri önünde hak arama hürriyetine sahiptir. Ancak, yargılama süreci uzun süreli ve ekonomik olarak masraflı bir süreçtir. Ancak, kişiler, dilek ve şikayetleri hakkında, idari makamlara müracaat etme hakkına da sahiptirler. Kişilerin dilek ve şikayetlerini iletmek için idari makamlara yaptıkları müracaatlar, idari başvurular olarak ifade edilmektedir. İdari başvuru yöntemi yargı yoluna oranla daha az masraflı ve daha k1sa sürede neticelenebilecek bir yöntemdir.

İdari başvurular, kişilerin daha kolay bir şekilde haklarını arayabilecekleri bir yöntem olmasına rağmen, Kanun Koyucu, bazı durumlarda yarg1 yoluna başvurmadan önce idari başvuru yapılmasını zorunlu kılmıştır. Zorunlu idari başvurunun öngörüldüğü durumlarda, kişiler, ancak, idari başvuru yollarını tükettikten sonra yargı yoluna başvurabilir. Diğer bir ifade ile zamanında usulüne uygun olarak idari başvuru yapmayan kişiler yargıya başvurma hakkını da kaybederler. Zorunlu idari başvuru öngörülmeyen durumlarda kişiler doğrudan yargıya gidebilecekleri gibi idari başvuru da yapabilirler. Fakat ilgili mevzuatta bir hak olarak düzenlenen ve ilgililerin isteğine bırakılan bazı idari başvurular, Danıştay tarafından dava hakkının kaybı şeklinde sonuçlanabilecek zorunlu bir idari başvuru olarak yorumlanabilmektedir

Danıştay kararlarına bakıldığında idârî başvurularla ilgili uyuşmazlığın daha çok 2577 sayılı Yasanın 10.,11.ve13. maddelerin düzenlenen başvurularla ilgili olduğu görülmektedir. Yaklaşık yüz civarında kararının incelendiği bu çalışmada idari başvurular konusunda, Danıştay kararları arasında içtihat birliğinin olduğunu söylemek mümkün değildir. Hatta aynı daire kararlarında bile içtihat farklılıkları vardır. $\mathrm{Bu}$ da uygulamada duraksamalara neden olmaktadır.

İdari başvuruların hak arama özgürlüğünün bir parçası olduğu düşünüldügünde Danıştay tarafından bu özgürlüğün mümkün olduğu

${ }^{90}$ Danıştay 12.D., 06.01.2006, E.2004/4383, K.2006/8, Danuştay Dergisi, S.113, s.393.

${ }^{91}$ Danıştay İdari Dava Daireleri Kurulu, 14.11.2006, E.2003/1009, K.2006/2127, Danıştay Dergisi, S.115, s.61. 
müddetçe geniş tutulması ve bu yolun kullanılması ya da kullanılmamasının ilgilisi açısında bir hak kaybına neden olmaması gerektiği tartışmasızdır.

Son olarak, ilgilileri tarafından yapılan idârî başvuru üzerine başvuru yapılan idarece konu tam olarak araştırılmalı ve konuya ilişkin başvuru sahibine doyurucu ve gerekçeli yanıtlar verilerek uyuşmazlığın idârî davaya konu olmadan çözümlenmesi sağlanmalıdır. Bunun için halen gündemde olan Genel İdari Usul Yasa Tasarısının kanunlaşmalıdır. 


\section{KAYNAKLAR}

AKYILMAZ, Bahtiyar İdare Hukuku, Sayram Yayıları, Sayram Yayınları, Konya, 2005.

ALAN, Nuri, "İptal Davalarının Ön ve Esastan Kabul Şartı”, Danıştay Dergisi, Y11:13, S.50-51, 1983.

ATAR, Yavuz; Türk Anayasa Hukuku, 3. bas1, Konya 2005.

BAL, Yakup - KARABULUT, Mustafa -ŞAHIN, Yahya, İdari Yargilama Usulü ile İlgili Danıştay 10. Dairesinin Seçilmiş Kararları, Ankara, 2003.

BİLGIN, Hüseyin: Belediyelerin Taşınmaz Mal Zilyetliğine Yapılan Tecavüzlerin İdari Yoldan Önlenmesi, Ankara, 2005.

CANDAN, Turgut, Açıklamalı İdari Yargılama Usul Kanunu, 2.bası, Ankara 2006.

ÇIRAKMAN, Erol, "İdari Davalarda Süre”, İdare Hukuku ve İdari Yargı ile İlgili Incelemeler, C:1, Ankara, 1976.

COŞKUN, Sabri / KARYAĞDI, Müjgan, İdari Yargılama Usulü, Seçkin Yayınevi, Ankara, 2001.

DEMIRKOL, Selami - BEREKET, Zühal, İdari Yargıda Dava Açma ve Davaların Takip Usulü, Ankara, 1998.

DURAN, Lütfi, "İdari Müracaatlar ve Bunların Karşısında İdarenin Sükutu”, I.Ü.H.F.M. C XII, S.1.

ERKUT, Celal, İdari İşlemin Kimliği, Danıştay Yayınları, Ankara, 1990.

EROĞLU, Hamza, İdare Hukuku, 3.bas1, Ankara, 1978.

ERDOĞAN, Mustafa, Anayasa Hukuku, 3. Bas1, Ankara, 2005.

GÖZÜBÜYÜK, Şeref - TAN, Turgut, İdare Hukuku, İdari Yargılama Hukuku, C.II, Turhan Yayınları, Ankara,1999.

GÖZÜBÜYÜK A. Şeref - DİNÇER, Güven, İdari Yargılama Usulü, 2.bas1, Turhan Yayınları, Ankara, 1999.

GÖZÜBÜYÜK, A. Şeref; Yönetsel Yargı, 13.bası, Turhan Yayınları, Ankara, 1999.

HONDU, Selçuk, "İdari Yargılama Usulü Kanunu'nda Yer Alan İdari Usuller ve Uygulaması", İdari Usul Kanunu Hazırlığı Uluslar arası Sempozyumu, 17-18 Ocak 1998, Ankara. 
KALABALIK, Halil, İdari Yargılama Usulü Hukuku, 2.bas1, Değişim Yayınları, Sakarya, 2006.

KAPLAN, Gürsel, İdari Yargıda Dava Açma Süreleri, Turhan Yayınevi, Ankara, 2007.

SEZER, Yasin, "Kamu Mallarında Ecrimisil", Danıştay Dergisi, S.108, 2004.

SOYBAY, Selçuk, İdarenin Yargısal Olmayan Biçimlerde Denetimi, (Yayınlanmamış Doktora Tezi), İstanbul Üniversitesi sosyal Bilimler Enstitüsü.

TOPUZ, İbrahim - ÖZKAYA, Kadir, İdari Yargılama Usulü Kanunu, Ankara, 2002.

YENİCE, Kazım - ESIN, Yüksel, Açıklamalı - İçtihatlı - Notlu İdari Yargılama Usulï, Ankara, 1983.

YILDIRIM, Ramazan, İdare Hukuku Dersleri, Mimoza Yayınları, Konya, 2006.

YILDIRIM, Ramazan, İdari Başvurular, 2.bası, Mimoza Yayınları, Konya, 2006. 